\title{
THE LACHRYMAL GLAND
}

\section{JOHN SUNDWALL}

From the Hull Anatomical Laboratory, University of Chicago and the Department of Anatomy, the University of Kansas

TWENTY FIGURES

\section{CONTENTS}

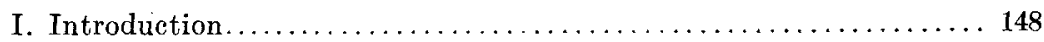

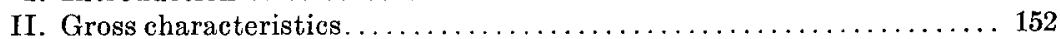

Gross structure and relations......................... 152

Vascular supply.................................. 153

Nerves....................................... 153

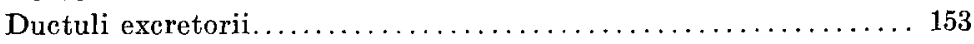

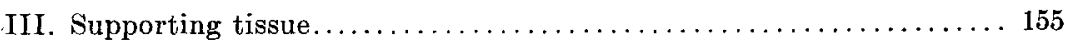

Capsule........................................... 155

The interlobular septa.............................. 156

The intralobular septa............................. 157

Elastic fibres................................... 157

Peritubular connective tissue, etc......................... 158

Plasma cells..................................... 161

IV. Duct system and tubules............................. 162

Injection-corrosion specimens of duct system ................ 163

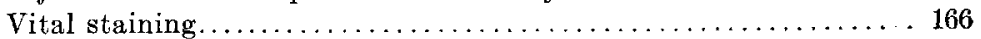

Histological structure of ducts and tubules:

Main duets..................................... 167

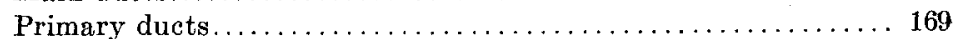

Interlobular ducts................................... 171

Intralobular ducts................................ 173

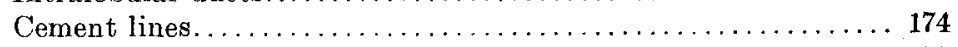

Intercalary ducts.................................. 175

Tubules........................................ 179

V. Secretion granules............................. 180

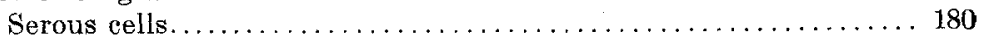

Mucous cells.................................... 181

Similarities of mucous and serous cells.................. 182

Granules in lachrymal gland:

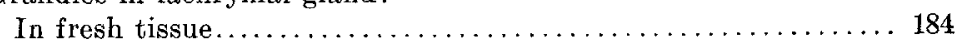

In fixed and stained preparations. . . . . . . . . . . . . . 188

Discussion of Granules.......................... 193 


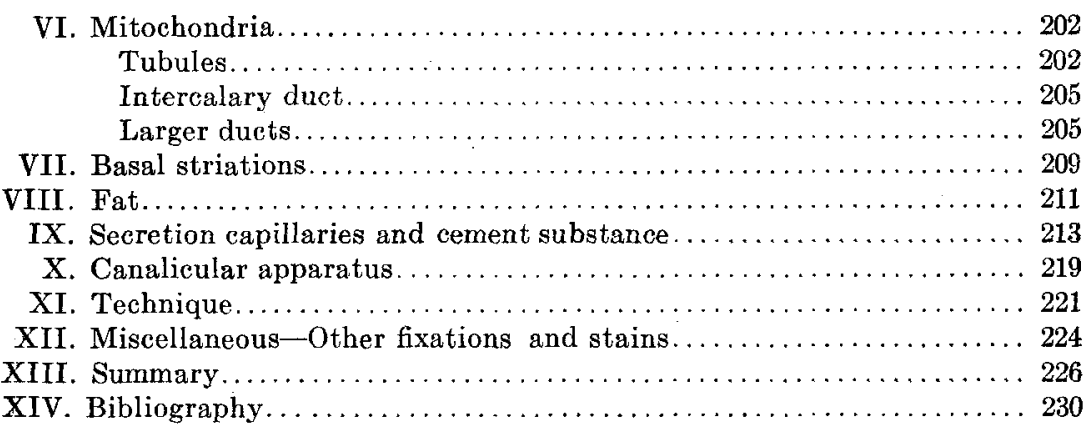

\section{INTRODUCTION}

The investigations on which this paper is based began several years ago ('05) when it was first learned that lachrymal glands as well as those of the nictitating membrane, plica semilunaris, of many animals stain with certain dyes which are generally regarded as specific to mucous secreting cells. It was found that these glands of the ox, pig, sheep, goat, and horse stained readily with either mucicarmin or muchaematein, while those of the cat, $\mathrm{dog}$, rabbit, and guinea pig did not. Preparations of the lachrymal glands of these animals were shown at the twenty-second session of the Association of American Anatomists held at the University of Wisconsin, and a preliminary report on the staining reactions of the lachrymal gland tissue found in the nictitating membrane of the ox was published in 1906.

It was the intention at that time to publish in detail the results of the investigations on the staining characteristics of these glands. There was a delay, however, and in the meantime a paper by Hornickel ('06) on this particular subject appeared. In this he claimed that by the use of mucicarmin a positive stain was obtained on the lachrymal glands of the pig, sheep, goat, and dog, while similar glands of the horse, ox, ass, and cat were negative. His results in some instances were opposite to mine; namely, I obtained a positive stain in these glands of the $\mathrm{ox}$ and horse while the glands of the dog were negative. The difference in the results obtained in the two laboratories is interesting. Hornickel's paper served as added impetus to further 
work on my part, and I decided that a detailed study of the structure of this gland in one species might well precede a general comparative study.

In view of the work already begun on the Harderian gland in Bos and the availability of the lachrymal gland in this species for both structural and chemical study, it was chosen for this purpose.

Numerous contributions have appeared dealing with various phases of the lachrymal gland of different animals - such as its phylogeny, embryology, innervation, gross and microscopic structures, etc. Chief efforts, however, have been directed toward the study of the structure of the cells and the secretory changes they undergo during the stages of rest and activity.

The origin and distribution of the gland in vertebrates have been described by Wiedersheim ('76) and Sardemann ('87). Wiedersheim ('07) states:

The first attempt of a vertebrate to exchange an aquatic for an aerial existence necessitated the development of a secretory apparatus in connection with the eye. Thus in Urodeles a glandular organ is developed from the conjunctival epithelium along the whole length of the lower eyelid; in Anurans and Reptiles this becomes more developed in the region of the anterior, and in many Reptiles also of the posterior angle of the eye, the original connecting bridge gradually disappearing: thus two glands are developed from the primitively single one, each of which becomes further differentiated both histologically and physiologically. From one is formed the Harderian gland-anterior angle of the eye--while the other, posterior angle, gives rise to the Lachrymal gland. In Crocodiles, Snakes, and Hatteria, the lachrymal gland is wanting while in the Chelone it is extremely large.

Further contributions regarding the comparative anatomy of the lachrymal gland are given by Van Trotzenburg ('01) who studied it in both the old and new world monkeys and its phylogenetic relation to man.

Contributions to the embryology of this gland and its accesory structures have appeared from time to time. Falchi ('05) studied the development of the gland in the rabbit, guinea pig, sheep, and human. Monesi ('03), Matys ('05), ('06), Küsel ('06), and Lang ('11), also, have contributed to this phase of the subject. Their efforts, however, have been concerned chiefly with 
the lachrymal sac and canal. Speciale-Cirincione ('08) states that in man- "Die Anlage der Tränendrüse beginnt mit dem 2. Monat, zu einer Zeit, wo die Lidspalte noch weit offen steht. Die Entwicklung geht alsdann sehr rasch vor sich, so dass von einem Tage zum anderen eine erhebliche Aenderung zu bemerken ist."

The innervation of the lachrymal gland has been studied by Dogiel ('93), Jendrássik ('94), Tepliachine ('94), Laffaye ('97), W. Klapp ('97), P. Klapp ('97), Landolt ('00), Puglisi-Allegra ('03) ('04), and Schirmer ('04). The works of Dogiel and Puglisi-Allegra are of particular interest here as the others are chiefly contributions from a clinical standpoint.

Dogiel used the methylene-blue and Golgi's methods on the lachrymal glands of the guinea pig and rabbit. According to him "Die Thränendrüse empfängt fast ausschlieslich marklose Nervenfasern, solche, die Blutgefässe und die Ausführungsgänge umflechtend, . . . und bilden ein Geflecht in dem auf der memb. Propria derselben sich lagern." A peritubular and intercellular net work of these fibers is described.

Puglisi-Allegra ('03), using Golgi's method and the vital staining with methylene-blue, describes peritubular, intrapericellular, intracellular fibres, and sympathetic ganglia cells situated on the course of the sympathetic fibres.

Schirmer describes both medulated and nonmedulated nerve fibres in this gland.

Clinical observations seem to favor the view that the secretory fibres are derived from the facial nerve through the Nervus petrosus superficialis major by way of the Ganglion Sphenopalatinum (Klapp).

The vascular supply and lymphatics have been studied by Puglisi-Allegra ('04).

The position and gross characteristics of the gland have been described by Ellenberger ('06) and by Ellenberger and Baum ('08).

Regarding the finer structures of the gland there have been many contributions. Not all are agreed, however, as to the form of the secreting elements (whether tubules or alveoli). 
Leydig ('57), Frey ('59), Henle ('73), Ellenberger ('88), Toldt ('01), V. Ebner ('02), Böhm and Davidoff ('03), and others have described the lachrymal gland of man and domestic animal as being in general tubulo-acinous in form. Flemming ('88), Stöhr ('91), Zimmermann ('98), Sobotta ('02), and Schirmer, among others, describe it as a compound tubular gland, while Franck ('83), Langer ('90), and Leiserung-Mueller-Ellenberger ('90) describe it as being of the acinous type.

Boll's ('68) research on the lachrymal glands of the pig, sheep, calf, and dog was one of the first of importance. His work was confined to the star-shaped supporting cells surrounding the alveoli. Later ('71) he compares the structure of this gland to that of the salivary gland.

Schwalbe ('87) divides the gland into "eine grössere compacte obere, die obere Thränendrüse (Glandula lachrymalis superior s. innominata Galeni; Portio superior s. orbitalis [Sappey] und eine kleinere aus locker geordneten Läppchen gebildete untere, die untere Thränendrüse (Glandula lachrymalis inferior s. glandulae congregatae Monroi; Portio inferior s. palpebralis [Sappey])."

Much of the later investigation has been confined to the study of secretion granules and the secretory changes in the lachrymal gland during rest and activity. Among the most important of these are the contributions of Langley ('79), Reichel ('80), Nicolas ('92), Solger ('96), Kolossow ('98), Lor ('98), Noll ('01), and Puglisi-Allegra ('04).

Maziarski ('02), using the method of Born, constructed a model of the human lachrymal gland. "Es ist eine deutlich tubulöse Drüse; es wäre also ganz unrichtig, sie mit den Speicheldrüsen zu vergleichen."

Fleischer ('04) follows with an extensive article on the structure of the lachrymal gland of the ox.

Numerous other contributions have appeared dealing with special phases of the lachrymal gland, among which may be named Merkel ('83), Kirchstein ('94), Stanculéanu and Théorhari ('98), Garnier ('00), Axenfeld ('00), Alt ('00), Dubreuil ('07), Gotz ('08), and Riquier ('11). 


\section{GROSS CHARACTERISTICS}

The following description of the lachrymal gland in the ox is made from careful dissections after embalming heads and injecting the arteries.

\section{Gross structure and relations}

The gland in general is a flattened oval or almond shaped structure situated on the superior contour of the bulb, with an auricular appendage which descends on the outer or posterior contour of the bulb. The gland is more or less moulded to conform with the bulb and the bony orbit so that the superior surface of the oval mass as well as the outer surface of the appendage is convex in contour while the surface directed towards the bulb is concave. Both surfaces possess the characteristic glandular lobulations.

The anterior or outer margin of the gland including the appendage measures on an average from 5 to $5.5 \mathrm{~cm}$. in length. The long axis of the superior mass is from 3 to $4 \mathrm{~cm}$. in length, the average width of the mass being $3 \mathrm{~cm}$. and its average thickness $1 \mathrm{~cm}$. The superior mass is generally termed the Pars superior while the appendage is known as the Pars inferior or accessorius. The Pars inferior or appendage generally measures about $2 \mathrm{~cm}$. in length, $1 \mathrm{~cm}$. in width, and $4 \mathrm{~mm}$. in thickness, but this portion of the gland is subject to much variation.

The weight of the entire gland mass averages in the adult ox from 6 to 7 grams. The weight of the appendage (Pars inferior) is from 1 to 1.5 grams. It will be seen from a comparison of these weights that the larger mass of the gland is confined to the Pars superior.

The Pars superior is situated on the superior and posterior or temporal half of the Bulbus oculi while the long axis of this oval shaped mass is directed obliquely posteriorly and medianward. The anterior pole is located immediately above the insertion of the M. levator palp. sup. and M. obliquus sup. This corresponds to a point immediately behind the center of the Margo supra orbitalis. From this point, the lateral margin of the Pars super- 
ior extends to the posterior or temporal canthus just under and slightly within the Margo supra orbitalis. At this point the Pars inferior or appendage takes origin and extends downward and behind the bulb, just within the bony orbital wall. It terminates at the level equal to the insertion of the $\mathbf{M}$. obliquus inf. and the inferior margin of the insertion of the M. rectus lateralis.

The gland is completely enclosed within the orbit by the periorbital fascia, a thick fascia which surrounds and encloses all the structures of the orbit and lines the bony orbital wall. The gland itself is embedded and surrounded by a condensed and tough mass of areolar tissue and fat which is a part of this general tissue which fills the interstices between the muscles, nerves, and bulb. Bands of dense tissue derived from the inner surface of the periorbital fascia are fused with the capsule of the gland.

\section{Vascular supply}

The gland derives its blood supply from the A. lacrimalis which is a branch of the A. ophthalmica. The artery enters the gland from the interior or bulbar surface by numerous branches. A branch of this artery continues and enters the superior palpebral fascia. Corresponding veins leave the gland and are collected into the V. lacrimalis which empties into the V. ophthalmica.

\section{Nerves}

The innervation is from the $\mathrm{N}$. lacrimalis. Two distinct lachrymal nerves take origin from the $\mathrm{N}$. ophthalmicus near its origin. These nerves follow the general course of the blood vessels (fig. 1.)

\section{Ductuli excretorii}

From six to eight ducts carry away the secretion of the gland. These ducts leave the lateral margin of the gland, enter the palpebra superior and terminate by piercing the superior conjunctiva about $1.5 \mathrm{~cm}$. internal to the free margin of the superior 


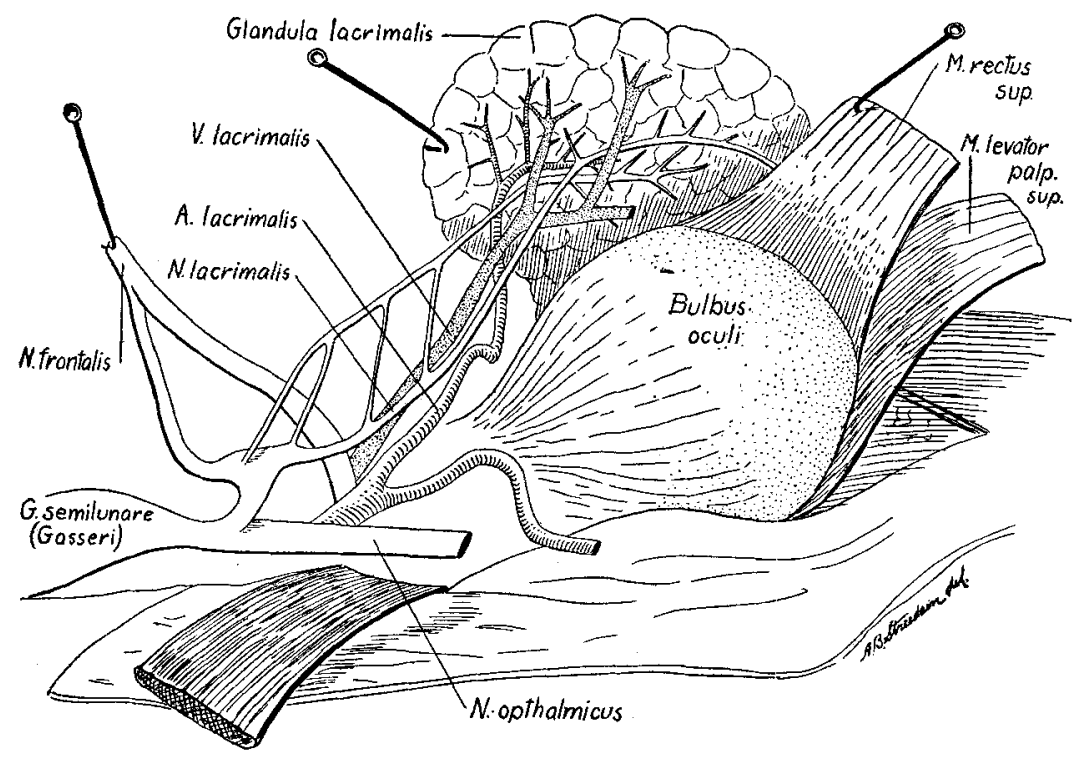

Fig. 1 Gross structure of gland showing relations. From dissection, Tech. I. Concave surface with vessels and nerves are shown.

lid. These terminals are arranged in a straight line on the conjunctiva extending from its center to the external or posterior canthus. The distance between these terminals averages about $0.5 \mathrm{~cm}$. The openings readily admit a porcupine quill (fig. 2 ).

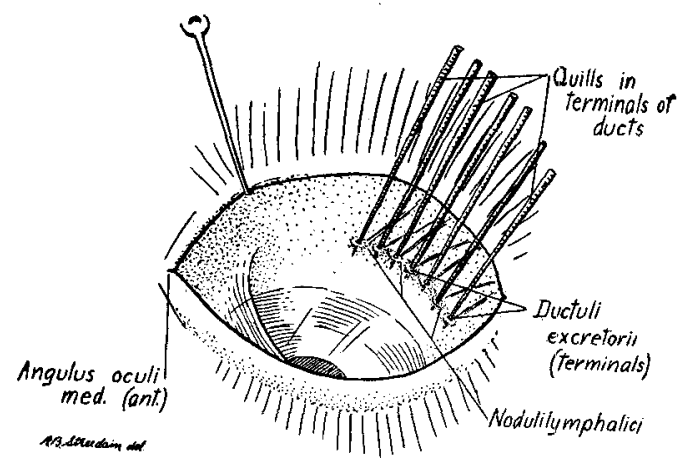

Fig. 2 Terminals of Ductuli excretorii with quills inserted. From tissue prepared by Tech. I. 
The ducts range from $1.5 \mathrm{~cm}$. to $2 \mathrm{~cm}$. in length. They are more or less tortuous in their course as it is impossible to obtain a duct in its entirety even in thick sections. There are seen on the conjunctiva surrounding these terminals aggregations of lymph nodes. From four to six ducts leave the Pars superior while from one to two leave the Pars inferior (fig. 3).

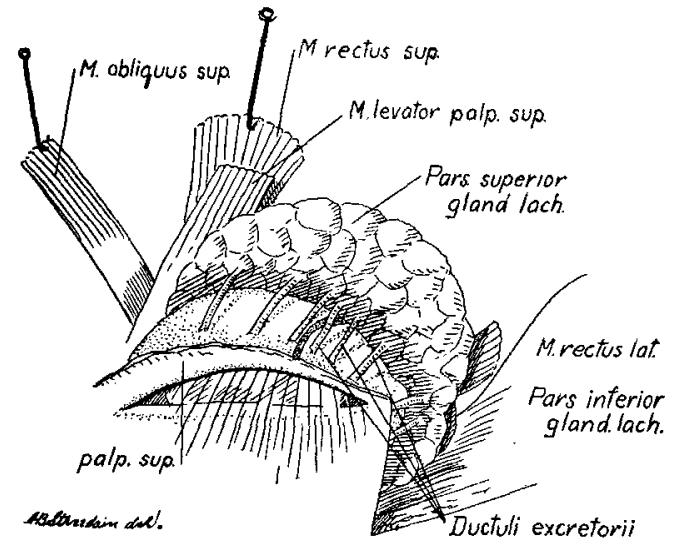

Fig. 3 Pars superior; Pars inferior; Ductuli excretorii. Specimen prepared by Tech. I.

\section{SUPPORTING TISSUE}

For the study of the capsule and connective tissue framework of the gland the methods and stains used were: Flint and Spalteholz, Mall's method and a modification of his method for the demonstration of reticulum, Mallory's, Van Gieson's, Weigert's, and Herxheimer's. (See Technique.)

\section{Capsule}

The capsule is fused with the general areolar and adipose tissue of the orbit. Strands of tough connective tissue fibres derived from the periorbital fascia are also intimately fused with the capsule. It is bound down to the gland by numerous interlobular septa which take origin from the capsule and ramify throughout the gland thus separating it into numerous lobules. It varies in thickness. In general that portion covering the 
convex surface is thinnest, averaging $0.5 \mathrm{~m}$. Where the septa take origin in this area it is much denser. The thickest portion is found on the concave surface.

It is composed of areolar tissue in general. Both collagenic and elastic fibres are present in abundance. Numerous globules of fat are seen singly and in groups irregularly distributed through out, being more abundant around the large vessels. Small lobules of gland tissue are also included within the capsule. These are more numerous in the neighborhood of the exits of the main ducts. Smooth muscle fibres are also present irregularly distributed. On the concave surface the capsule contains the large blood vessels and nerves while on the outer margin of the gland the large ducts are surrounded by the capsular tissue. The elastic fibres are long and fine and are arranged parallel to the surface of the capsule, as described by Fumagalli ('97), Riquier, and Schirmer. They are most numerous on the concave surface where they surround the larger vessels. In the region of the exits of ducts the elastic fibres are abundant also and interlace more than elsewhere, forming a network around the ducts.

\section{The interlobular septa}

The interlobular septa, which are derived from the capsule and divide the gland into numerous irregularly shaped and sized lobules, are composed of practically the same tissues described in the capsule. Secondary septa take origin from two or three large primary septa and enter the various lobules, forming the supporting structures of the lobules and surrounding the various vessels, nerves, and ducts, which are in close proximity to each other.

Observations in this laboratory regarding the capsule and septa agree with those of Schirmer. However, I have failed so far to see in the connective tissue framework of the gland - septa or intralobular tissue - of either young or old Bovidae a constant accumulation of lymphoid cells such as described by Schirmer for man and Fleischer for the lachrymal gland of the ox. Axenfeld and Gotz have also referred to lymphoid infiltrations in 
man which increase from childhood to old age. According to Bensley these are probably plasma cells.

The supporting elements finally ramify and surround each acinus, or tubule, forming a network or reticulum. The larger septa contain fat and small glandular lobules in addition to the vessels, nerves, and ducts. The septa are composed chiefly of collagenic fibres (Van Gieson's). Elastic fibres are present to some extent in all the interlobular framework, especially around the ducts and vessels. Cells suggesting smooth muscle cells are sometimes seen, in addition to those seen in the vessel walls, occurring very sparsely and as a rule singly in the neighborhood of the ducts.

\section{The intralobular septa}

The intralobular connective tissue septa are practically composed of collagenic fibres and reticulum. In the larger of these, only, are elastic fibres seen independent of the vascular walls. In the smaller septa well within the lobules elastic fibres are seen only in connection with the blood vessels. No elastic fibrils are seen surrounding the alveoli of the gland.

\section{Elastic fibres}

My observations regarding the final distribution of elastic fibres do not entirely agree with Boll ('71), Schirmer, and Fumagalli, who claim that elastic fibres surround the alveoli, or tubules. Regarding these fibres Riquier remarks-" "nei sepimenti connettivali attorno ai vasi ed ai condotti escretori, sono invece difficilimente dimostrabili intorno ai tubuli secernenti."

My investigations indicate that elastic fibres do not enter the lobules and surround each tubule. Repeated examinations of tissues fixed in various solutions and stained both by Weigert's and the Unna-Taenzer method - the latter was used by the Italian investigators - did not show the presence of elastic fibres surrounding the acini.

In using these stains, it is most essential to fully decolorize the section. Otherwise the usual collagenic fibres and reticulum 
may assume the staining characteristics of elastic fibres. This is especially true of the Unna-Taenzer orcein method which stains elastic fibres brown. It was my practice to place the sections from the stain in 70 per cent alcohol and then decolorize under the microscope with acid alcohol until the section became for the most part colorless. The characteristic elastic fibres of the blood vessels remain deeply stained and serve as controls for the degree of decolorization. In the use of Weigert's it is also necessary to decolorize in alcohol until the section becomes yellowish or light gray. The elastic fibres alone should be stained black.

With the proper degree of differentiation, using the elastic fibres of arterial wall as the criterion, it will be found that elastic fibres are present, as described, in the capsule; to a less degree in the interlobular septa surrounding the blood vessels; and in the basement membrane of the main, primary, interlobular, and larger intralobular ducts. Only occasionally are they seen in the walls of the small intralobular ducts. They are not present as forming the walls of the acini except in rare instances, and then when lobules are in contact with capsule.

\section{Peritubular connective tissue, 'Korbzellen', basement membrane}

The finer structural tissue surrounding the terminal tubules or acini of glands in general is composed of several elements such as fixed connective tissue cells, the so called 'Korbzellen' or basket cells, and the basement membrane. Much confusion exists in the literature respecting the terms used to designate these various tissues. Some refer to all these elements as the basement membrane. Shafer ('12) states:

In most glands the secreting cells of the alveoli and also the cells which line the ducts are bounded. . . by a thin membrane, which is sometimes continuous, sometimes interrupted, and which has nuclei here and there scattered upon it. This is the basement membrane and as the presence of nuclei indicates, it is composed of more or less fused flattened cells of connective tissue nature which are sometimes united edge to edge, sometimes connected only by branch processes so as to form a sort of flattened basket-work around the alveoli. Even 
in this case the meshes of the basket-work are not quite empty, being occupied by a delicate filmy membrane which is a condensation of the reticular connective tissue.

Flint and others refer to this latter alone as the basement membrane.

Boll ('68) was the first to describe 'Korbzellen' in the lachrymal glands of the pig, sheep, calf, and dog. Owing to the resemblance of these cells, in transverse sections, to demilune cells, he regarded them as similar in nature to those cells described by Gianuzzi in salivary and mucous glands. Cells similar in structure had been described in other glands by Krause; Henle, who regarded them as nerve cells; Pflueger; and von Kölliker. Others held the same view as Boll regarding the function of these cells. Noll ('01) regarded these 'Korbzellen' as having completed a stage of secretion and having been pushed back against the wall by neighboring cells filled with secretion. In a later communication Boll ('71) refers to these cells as the basement membrane.

Kollosow refers to the cells described by Boll as muscular epithelium, as did Zimmermann ('98). Schirmer and PuglisiAllegra described similar cells in lachrymal glands, to which they ascribe the function of contractility.

These 'Korbzellen' are readily seen in my Zenker-Van Gieson preparations. They are more prominent in the lachrymal glands of younger animals. Frequently these irregular anastomosing cells are seen between the deep red staining reticular membrane and the epithelial cells of the tubules, often obscuring the latter. I am inclined to regard them as of connective tissue origin rather than contractil musculo-epithelium. The anastomosing processes of the cells stain deeply red in Van Gieson's. Further work, especially of an embryological nature, will be essential to determine the positive nature of these cells.

Other connective tissue cells are seen in addition to these large cells-Körbe. These manifest themselves as elongated nuclei and lie alongside of the basement membrane. Occasionally nuclei appear at the intersection of the fibrils of the reticulum and as a consequence appear as a part of it. Nuclei of endothelial cells, lymph cells, and plasma cells are also seen. 
The basement membrane proper has been described by Zimmermann and Fleischer in the lachrymal gland.

According to my observations, the final ramification of the supporting tissue is in the form of a reticulum enclosing within its meshes the acini, intercalary and intralobular ducts, and vessels. This reticulum forms the membranae propriae of the acini or tubules and consists of a delicate network of interlacing fibrils which intimately surround the epithelial cells of the acini and small ducts. From this basement membrane secondary

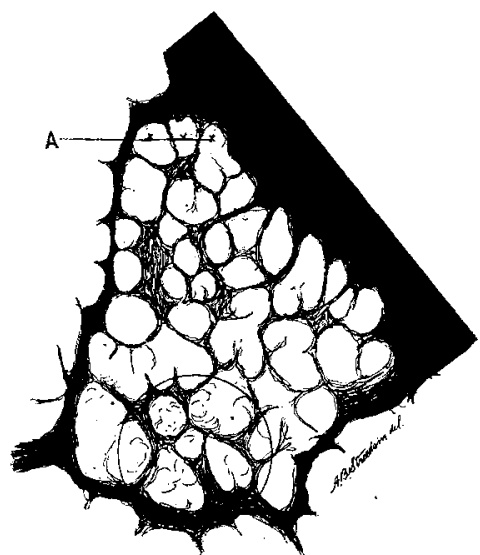

A

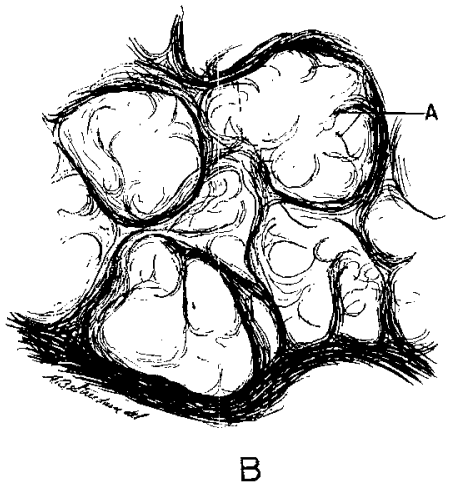

B

Fig. 4a Reticulum, Tech. III, 2, 3, Oc. 6, obj. 8, X 300. Parenchymatous and other tissue digested away in pancreatin. Reticulum is readily seen showing the outlines of the original tubules.

Fig. 4 b Reticulum, Oc. 2, obj. $2 \mathrm{~mm}$. oil, X770. Portion in figure $4 \mathrm{a}$ enclosed within the circle is shown here enlarged.

fibres apparently take origin and pass radially into the acini between the individual gland cells. Others may appear to enter the base of the cell, thus simulating Holmgren's Trophospongium. However, in reality this probably does not occur.

The basement membrane and its relation to the tubules, as described, can readily be seen in sections stained by Mallory's method, whereby it is stained dark blue. As a rule it is closely apposed to the epithelium, and the interepithelial processes are seen with ease. In Van Gieson's stain it is red. This network 
can be considered as reticular connective tissue in the sense of Mall, and is almost identical in appearance to the reticular framework of the submaxillary gland as shown by Flint. According to the Flint, Spalteholz method (Technique II, 1) and a modification of Mall's method (Technique III, 2) it was shown that this basement membrane is not digested in pancreatin while the parenchyma entirely disappears. Satisfactory specimens for study may be made by these methods and then staining by either Mall's or Mallory's method (figs. $4 \mathrm{a}$ and $4 \mathrm{~b}$ ). Van Gieson's stain also may be used. The presence of this basement membrane after prolonged digestion shows that elastic fibres do not compose it.

\section{Plasma cells}

Numerous plasma cells are seen in both the interlobular and intralobular tissue, principally around the ducts and between the acini. These cells are typical in appearance-round, more or less eccentric nuclei with peripheral arrangement of the chromatin, and fine basophilic granules in the protoplasm. These cells are differently shaped--some spheroidal, others elongated and irregular in outline. Sections stained in neutral safranin show these cells very clearly. They may be found singly or in clusters (fig. 5).

Since Waldeyer ('75) first designated certain cells as plasma cells and Unna ('92) described these cells as purely pathological in the skin, followed by other observers who stated that they are present in normal tissues, there have been numerous contributions regarding plasma cells and their distribution in glands. Klein ('79, '82) and Cajal ('96) describe them as being present in the submaxillary gland of man. Zimmermann shows in the lachrymal gland of man "Granulirte Zellen (Plasmazellen?) mit je zwei stäpchenförmigen Centralkörpern innerhalb eines granula freien Hofes." Plasma cells have been described also by Ioannovices ('99) in glands of the tongue, and by Maximow ('01) in submaxillary and retrolingual of the dog. According to the latter they are comparatively few in the submaxillary and numerous in the retrolingual. Krause ('98) calls attention to 
the relation of plasma cells to the secretory activity of the retrolingual gland of the hedge hog - they being fewer in number in the stimulated gland than in the resting. Dantchakoff ('05) observed the relation of plasma cells to the secretory activity of the submaxillary gland of the rabbit, and Hannes ('11) describes them in the lachrymal gland of man.

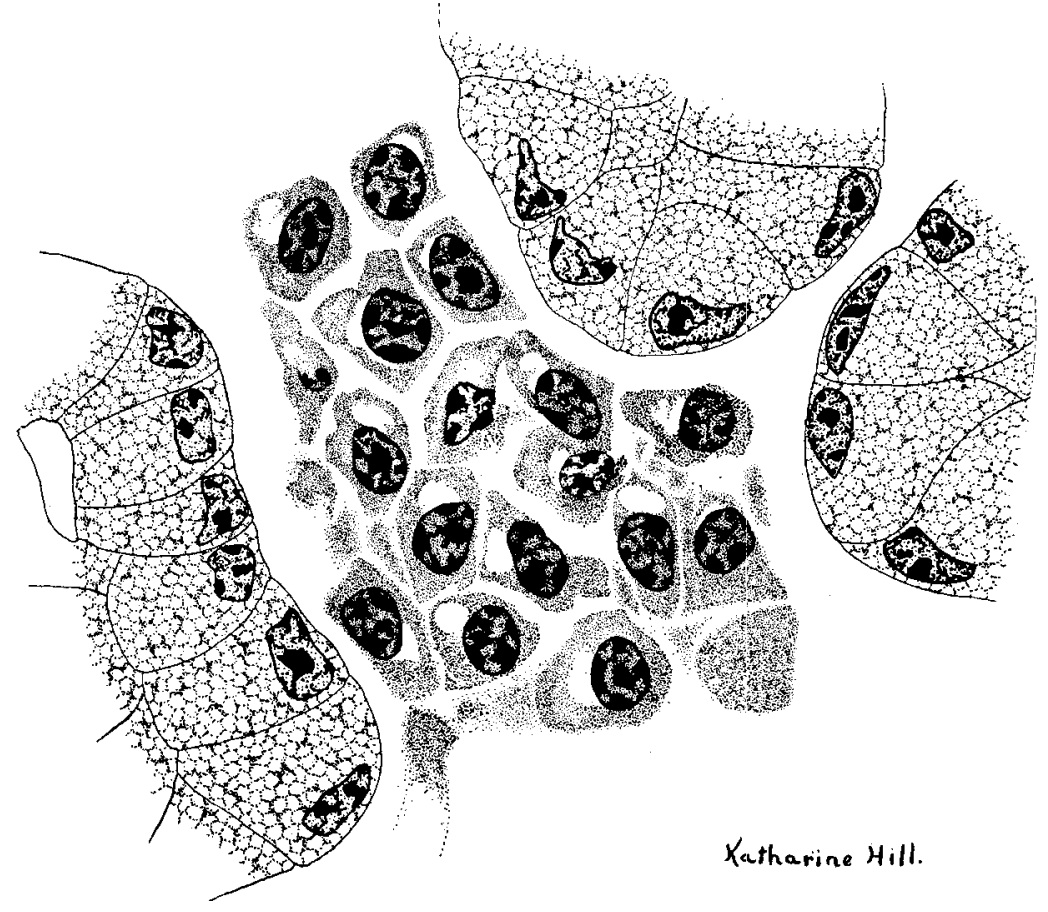

Fig. 5 Interstitial plasma cells. Oc. 4 , obj. $2 \mathrm{~mm}$, oil.

\section{DUCT SYSTEM AND TUBULES}

For purposes of description I have adopted the following classification of the duct system; (1) main ducts, Ductuli excretorii; (2) primary ducts; (3) interlobular ducts; (4) intralobular ducts; (5) intercalary ducts; and (6) acini, alveoli, or tubules. I see no reason for the inclusion of separate sublobular ducts in the lachrymal gland. 
The methods used for the study of the duct system have been as follows: (1) injection methods, (2) vital staining with pyronin, and (3) histological study of sections.

The injection-corrosion specimens of the duct system as prepared in this laboratory (Technique II, 2)

The main duct follows a more or less tortuous course through the palpebral fascia and enters into the gland substance at the outer margin. At this point it is seen to branch. The branching is somewhat variable-generally two different types are seen: (a) a dichotomous branching wherein the main duct divides into two ducts, which by the same method immediately form four ducts, etc. (This method of branching is described for the submaxillary glands by Flint) and (b) the main duct may continue for some distance into the gland substance somewhat similar to the trunk of a poplar tree, while the primary ducts take origin from this main trunk at various levels. In both instances, however, before the primary ducts take origin, several small branches are seen to leave the main duct at right angles. These are the ducts of small accessory lobules located on the outer or lateral margin of the gland.

The primary ducts vary in length, depending upon their distribution. They divide, as a rule, dichotomously into either equal or unequal branches. In the former case, where the branches are equal, these immediately undergo dichotomous branching again to form the interlobular ducts. Where the branches are unequal, the smaller one may directly form an interlobular duct, while the larger one may continue as a primary duct for some distance farther and then branch to form interlobular ducts. Frequently very small branches take origin directly from the primary ducts at right angles as in the case of the main ducts. These small branches are intralobular ducts which empty directly into the primary ducts from neighboring lobules.

An extensive ramification of the interlobular ducts is seen. The branching is much similar to that described for the primary 
ducts -(a) dichotomously or (b) the main interlobular ducts continuing as such for some distance with smaller intralobular ducts taking origin at various levels.

The intralobular ducts have an extensive ramification as well. The branching is chiefly of the dichotomous type although trichotomous branching is seen. The branches are as a rule very unequal in calibre. Each lobule as a rule contains many of these ducts of unequal sizes. At various levels in the course of these ducts, nodular enlargements are seen. Frequently the ducts are seen to terminate in nodular enlargements. It is somewhat difficult to force the injection mass beyond these nodules. However, after careful and repeated trials it is possible to force it (celloidin is preferable) to the alveoli or tubules and

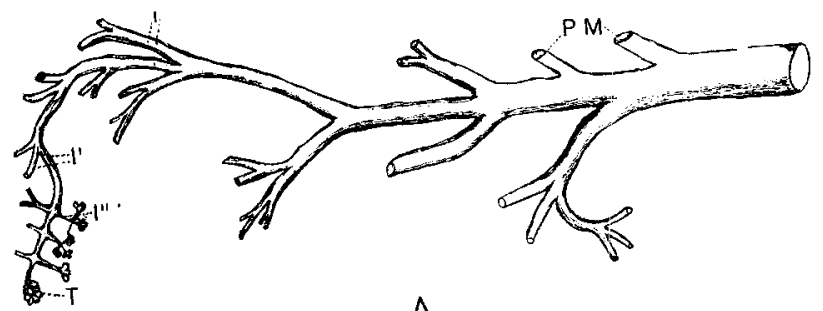

A

Fig. 6a Corrosion east of main duct with branches. Drawing, binocular, somewhat diagrammatic. $M$, main duct; $P$, primary duct; $I$, Interlobular duct; $I^{\prime}$, intralobular duet; $I^{\prime \prime}$, intercalary duct; $T$, tubules.

when this is accomplished it is seen that these nodules mark the exits of the intercalary or junctional duct.

The lumina of the intercalary ducts are exceedingly fine and threadlike as represented by the celloidin or celluloid cast. As a rule two or three of these ducts leave each nodule at right angles to the intralobular ducts and terminate in the tubules. Frequently they are seen to undergo dichotomous and in some instances trichotomous branching before so terminating. From two to three tubules mark the termination of the intercalary duct.

The entire duct system belonging to one main duct forms an elongated gland (fig. 6 a). Generally the primary duct leaves the main duct at an acute angle. The branching of the secondary 
duct system-interlobular and intralobular ducts-is similar. The intercalary ducts, on the other hand, as a rule branch off at almost right angles or even greater angles from the intralobular ducts from which they have origin (fig. $6 \mathrm{~b}$ ). Of course there are numerous exceptions to this generalization, but it is not by any means imaginative to compare these corrosion casts of the lachrymal gland to six or eight trees varying in length and placed in a line so closely that the smaller branches and leaves intermingle. The main trunks are then comparable to the Ductuli excretorii; and the primary, secondary, and tertiary, etc. branches to the primary, interlobular, and intralobular ducts. The leaves represent the acini or tubules and their stems the intercalary ducts.

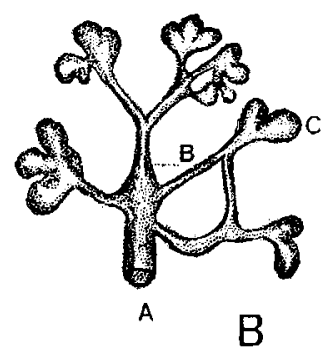

Fig. 6b Corrosion cast. High power drawing, projection apparatus. $A$, intralobular duct; $B$, intercalary duct; $C$, tubule.

In preparations where the mass has not passed beyond the nodular enlargements of the intralobular ducts the branching is readily observed through the binocular microscope. If the mass has passed into the tubules the duct system is greatly obscured. For the study of the intercalary ducts and tubules, small pieces were teased off and mounted on slides, then studied by high power.

It must be appreciated that in the study of corrosion casts, it is impossible to classify with certainty the various ducts; i.e., one cannot differentiate between the larger intralobular and the smaller interlobular ducts. As an auxiliary to this study carmin gelatin was injected into the ducts of other glands and sections of these tissues were prepared. In the latter preparations the 
diameters of various ducts were ascertained and then compared with the former. Even with this aid it was impossible (and not essential) to classify all ducts.

\section{Vital staining}

Vital staining with pyronin (Technique VI, 1) greatly facilitates the study of the smaller ducts and their distribution. Bensley found that the entire duct system of the pancreas was stained

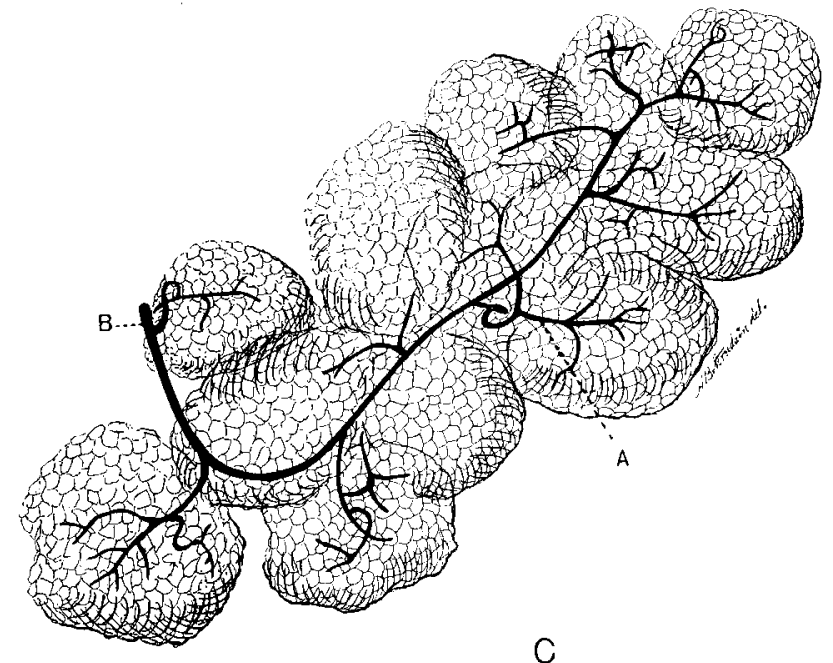

Fig. 6c Lobule of gland, fresh, after vital staining with pyronin. Drawing, binocular. The lumina of ducts are deeply stained red. $A$, intralobular duct; $B$, interlobular duct.

by this method. In application of his methods to the lachrymal gland it was found that its duct system stains a deep red while the tubules are only faintly stained (fig. $6 \mathrm{c}$ ). In the larger ducts the stain is limited to the periphery of the lumen, while in the smaller ducts the entire lumen stains. The smaller intralobular and intercalary ducts are especially prominent, and when fresh sections $0.5 \mathrm{~mm}$. thick are examined through the binocular microscope the ramifications are clearly seen. The deep red ducts can be readily traced, in thin sections, to the acini. Very 
thin sections of this tissue previously fixed in ammonium molybdate (Technique VI, 1) show that all the intercellular secretion capillaries are stained. See Secretion capillaries.

\section{Histological structure of ducts and tubules}

Main ducts. The excretory ducts in the superior lid are so tortuous in their course that it is impossible to obtain a continuous duct in longitudinal sections-only portions of one duct can be obtained. The ducts lie close to the conjunctival surface. As the terminal of the duct is approached there is seen a gradual increase of lymphoid tissue which surrounds the terminal openings as true lymph nodes.

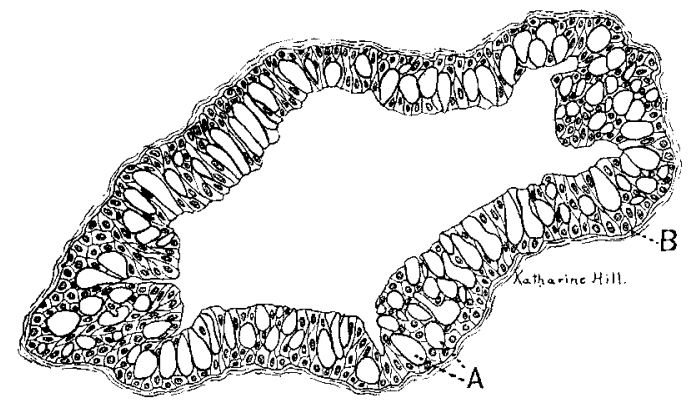

Fig. 7 Epithelium of main duct. Drawing, Zeiss, oc. 4, obj. 8, as seen in cross section of duct near its terminal in lid. $A$, goblet cells; $B$, epithelial cells. The large clear goblet cells are readily seen surrounded by smaller epithelial cells.

A cross section of the duct near its terminal shows the following characteristics: The lumen is either slit-like or very much corrugated, the epithelium being thrown up in folds with crypts between. Two types of cells line the duct-goblet cells and more or less irregularly elongated or cuboidal epithelial cells arranged in layers (fig. 7). The former cells occur in great numbers. They average as a rule $40 \mu$ by $20 \mu$ although there is much variation. Sections stained in iron haematoxylin and counterstained with mucicarmin show the surface epithelium to the best advantage. Here the goblet cells are stained red and can readily be differentiated from the epithelial cells in general. Many of 
these goblet cells reach the lumen and from the ends secretion masses can be seen projecting into the lumen. Others again do not reach the surface but are entirely surrounded by the general epithelium. As a rule a flattened nucleus is seen in the base of these cells and a definite network is seen in the cytoplasm. (fig. 8).

The epithelial cells show great irregularity as to form and size. They occur in several layers. In the crypts usually two layers are seen while in the folds three or even six layers of cells are seen arranged irregularly. Those bordering on the surface (superficial cells) are usually elongated and the base is drawn out into a wedge shaped process which projects downward between the

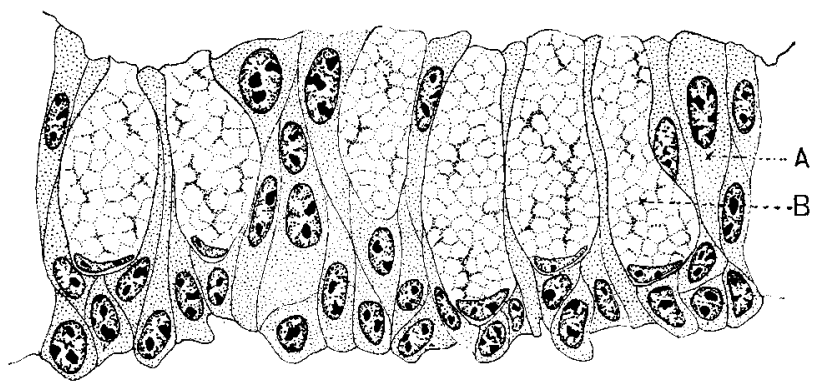

Fig. 8 Epithelium of main duct. Zeiss, oc. 4, obj. $2 \mathrm{~mm}$. oil. A, epithelium; B, goblet cells.

deeper layers of cells. In the crypts these wedge-like projections may reach the basement membrane. The deeper layers of cells are smaller as a rule than the superficial cells and are irregularly cuboidal or polygonal in shape. The deepest layer of cells borders on a basement membrane which is readily seen in sections stained by Mallory's method. The epithelial cells in general stain deeply and homogeneously in the usual stains. Reference is made to mitochondria later on. No secretory granules can be made out in any of these cells. The nuclei are prominent, oval or spheroidal, and show irregular clumps of chromatin. As a rule no definite nucleolus is seen.

The basement membrane is directly surrounded by a circular coat of connective tissue which averages from 100 to $150 \mu$ in 
thickness. The inner portion is very cellular containing numerous lymphoid cells, while the outer boundary is more or less fibrous. This outer boundary is immediately surrounded by the general connective tissue of the palpebral fascia. Sections stained by Van Gieson's method show the presence of numerous small vessels accompanying the duct. Smooth muscle cells are also seen in this connective tissue coat. They occur as a rule singly and do not constitute a coat. Collagenous fibres greatly predominate.

Weigert's stain shows the presence of numerous interlacing elastic tissue fibres which form a more or less indefinite layer outside of the basement membrane.

Primary ducts. These ducts represent the first branches of the main duct and are very irregular in size. As a rule the lumina are round or oval and have an average diameter of $0.2 \mathrm{~mm}$. The primary ducts are embedded and surrounded by a large amount of connective tissue which is derived from the septa. The epithelial wall averages $20 \mu$ in thickness and is as a rule made up of several layers of cells--varying from two to three layers, the former predominating. In many instances, however, a single layer of long columnar cells forms the entire epithelial wall. Where two layers are present there is an interdigitation seen between the long columnar cells and the basal more or less irregularly cuboidal cells.

The cytoplasm of the surface layer in the usual fixatives stains homogeneously. The nuclei are either oval or round and have an average diameter of from 7 to $10 \mu$. Clumps of chromatin irregularly distributed are readily made out within the nuclei. In many stains a definite cell boundary cannot be made out. However, it is plainly seen in thin sections and especially after the use of iron haematoxylin.

The cells of the outer layer, or layers, are irregularly cuboidal in form. The nuclei and cytoplasm show the same staining characteristics as the inner layer. The nuclei of the outer layer are frequently so arranged that their long axes are parallel to the circumference of the duct, while those of the inner layer are radially arranged to the duct. This condition, however, is much more pronounced in the smaller ducts. 
Goblet cells are also seen in the primary ducts. They are not so numerous by any means as in the main ducts. Many transverse sections of the former may show none of these cells while others again may show fr $>\mathrm{m}$ one to three. Their staining characteristies are similar to those described for these cells in the main ducts (figs. 9 and 10).

The epithelial cells of primary ducts border on a more or less indefinite basal membrane, which stains a deep blue in Mallory's stain, and is derived from and is a condensation of the circular layer of collagenic fibres which surround the epithelium and form the duct wall. The average thickness of this connective
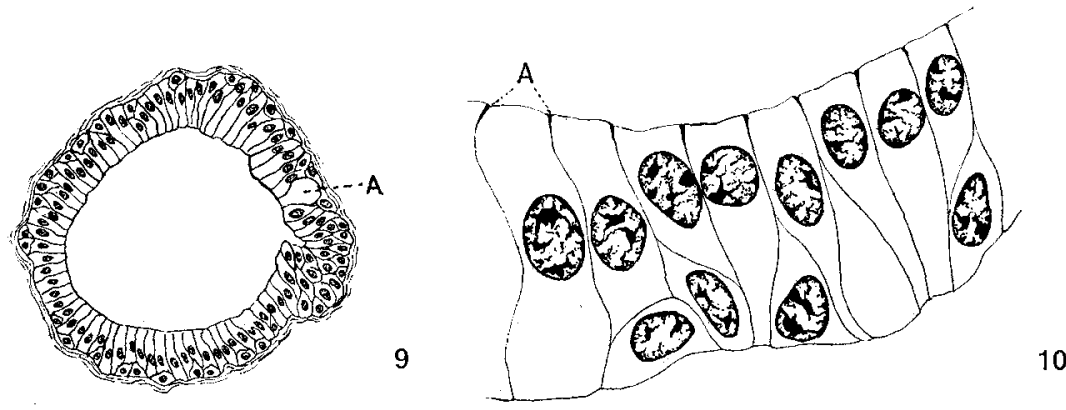

Fig. 9 Epithelium of primary duct, cross section. Zeiss, oc. 4 , obj. $8 \mathrm{~mm}$. A, goblet cell.

Fig. 10 Epithelium of primary duct. Enlarged drawing, Zeiss, oc. 4, obj. $2 \mathrm{~mm}$. oil. $A$, cement lines.

tissue wall is 50 to $100 \mu$. Its outer borders are gradually lost in the general connective tissue septa of the gland, which are always more abundant where these ducts are found. Long fine interlacing elastic fibres are present throughout the entire thickness of this circular connective tissue coat. Immediately surrounding the basement membrane these fibres form a closely interlacing layer similar to that described for the large main ducts. As the ducts become smaller, through ramification, there is a gradual decrease of these fibres and in some of the smaller primary ducts they are difficult to make out.

The chief component of the circular connective tissue wall is the collagenic or white fibrous tissue. The collagenic fibres 
stain deeply red in Van Gieson's. Within the interstices of these fibres many nuclear elements are seen which are (a) the nuclei of the endothelium, a rich plexus of arterioles, venules, and capillaries which are found in the walls; (b) lymphoid cells, which in very rare instances are so numerous that they obscure the collagenic fibres (I do not consider these lymph cell accumulations normal as they occur so infrequently); (c) occasionally solitary nuclei are seen in a cytoplasm which stains yellow in Van Gieson's. The structure of these cells, together with the staining characteristics, suggests that they are smooth muscle cells; (d) plasma cells are also seen.

In addition to the very small and numerous vessels which accompany and supply the ducts, large vessels and nerves are seen in close proximity to the ducts and following their ramifications to the gland substance. There is no regular distribution of these vessels, so far as numbers are concerned, in relation to the primary ducts. Sometimes only one of these larger arteries is seen in close proximity to a group of primary ducts. Frequently two are seen. Generally one large vein is seen to accompany these ducts. This is true also of the non-medullated nerves. However, much variation is the case with these as well.

Interlobular ducts. The primary ducts ramify to form the interlobular ducts. These further subdivide to form the intralobular ducts. It must be borne in mind, however, that intralobular ducts may originate directly from the main or primary duct. Again practically all of the primary ducts and even the main ducts for some distance are interlobular. Consequently the artificial subdivision of the duct system into primary, interlobular, and intralobular ducts must be accepted in a general sense only. In the following description of the interlobular ducts reference is made to those ducts which as a rule result from the ramification of the primary ducts and lie between the lobules.

The lumina of these interlobular ducts are wide and avorage as a rule about one-half to one-fourth the diameter of those of the primary ducts. Here again an explanation is necessary, for the diameters of the former are much larger at their origin than 
later on after ramification. The epithelial wall, which averages from 12 to $18 \mu$ in thickness, is composed of from one to two layers of cells similar in arrangement to those described for the primary ducts. The larger interlobular ducts generally possess two complete layers while in the smaller ones there is a noticeable reduction of the cells which form the outer layer. Consequently in these smaller ducts many of the epithelial cells extend down to the basement membrane.

The single layer cells are cylindrical in form. The cytoplasm stains deeply and evenly in the various cytoplasmic stains. Study of these cells by means of the oil immersion shows the cytoplasm to be very finely granular. No basal filaments or secretory granules can be seen in the general stains. I did not see in my preparations the central bodies described by Zimmermann. Tissues fixed in acetic osmic bichromate and stained in acid fuchsin-methyl green show numerous mitochondria. These are described under 'Mitochondria.' The cell boundaries are indefinite and only in the thinnest sections can they be made out clearly. As in the other ducts where a second layer of cells is present the inner layer sends basal processes between them which reach the basal membrane. The nuclei, which average from 6 to $8 \mu$, are round or oval and show the same staining characteristics as those of the primary ducts.

The cells in the outer layer, which, as already stated, are fewer in number, are more or less elongated-this elongation being parallel to the circumference of the duct. Here also the cell boundaries are indefinite. The cytoplasm stains similarly to that of the cells of the inner layer. In very thin sections both stain with the same degree of intensity. In thick sections, however, the inner layer appears more densely stained. This observation was made by Fleischer, who states, as a consequence, that the cytoplasm of the cells of the inner layer stains more intensely than does that of the outer layer. In my opinion this apparently deeper stain is due to the fact that these inner cells are more numerous and more compact, while those of the outer layer are fewer in number and more loosely surrounded by other cells. The nuclei of these cells are either oval or elongated, the 
long axes being parallel to the cirumference of the tubules. Here is seen a more pronounced example of the statement that the long axes of the nuclei of the outer layer are at right angles to the long axes of the nuclei of the inner layer cells. The cells of the outer layer are frequently so elongated that they resemble connective tissue cells. The nuclei of both layers are similar in staining characteristics.

The connective tissue wall surrounding the epithelium varies in amount depending upon the thickness of the septa in which the ducts are situated. A well defined basal membrane upon which the epithelial cells rest is plainly seen with Mallory's stain. Practically all the elements described for this wall under the caption of the primary ducts are seen in these wallswith a reduction in quantity, however. There is a marked decrease of elastic fibres. It is only necessary to contrast the smaller interlobular ducts with the larger primary ducts to appreciate this statement. In the wall of the primary ducts numerous elastic fibres are seen throughout the connective tissue wall while in the smaller interlobular ducts the elastic fibres occur sparsely or may not be seen. The accompanying arteries and veins, however, show these deep staining fibres in their walls and may be used for comparison. The decrease and disappearance of the elastic fibres take place between the origin of the primary ducts and the smaller interlobular ducts. The quantity of elastic fibres present is proportional to the thickness of the walls and septa in which the ducts are embedded. Where the connective tissue wall is much reduced and the septum is thin elastic fibres are only sparsely present or are not seen at all. The walls are composed almost entirely of collagenic fibres as revealed by Van Gieson's stain. Numerous cellular elements are present which may be classed similar to those of the primary ducts.

Intralobular ducts. Intralobular duct; vary much in the size of the lumina and the quantity of the surrounding connective tissue. Some ducts appear greatly dilated with lumina $70 \mu$ in diameter. These dilated ducts are not frequently found and are doubtless abnormal. Many again are seen which correspond 
in size and structure to the interlobular ducts. The intralobular ducts present as a rule the following characteristics. There is a reduction in the cells of the outer layer so that the smaller ducts appear to possess but a single layer of cells which show the same characteristics as those described for the interlobular ducts. The nuclei are elliptical. Frequently, however, one sees ducts with two layers of cells wherein the cells of the outer layer are as prominent as are the cells of the inner layer. This is true even in some of the smallest of the intralobular ducts. The connective tissue surrounding these ducts is much less abundant than that of the interlobular structures sometimes forming only a thin layer or again it may be considerable in quantity. It is derived from the intralobular connective tissue. Mallory's connective tissue stain shows a definite basal membrane. The wall is made up almost entirely of collagenic fibres. Only occasionally are elastic fibres seen. Capillaries are seen in these walls.

No secretory granules or secretion capillaries are present in these ducts. I did not observe by using the ordinary stains the basal filaments described by Hornikel in the cells of these ducts in the lachrymal gland of the ass and the more or less indefinite pencil like structures described by Fleischer in the ox. However these are seen in special preparations (see Basal striations). Merkel saw none in the lachrymal gland of the dog.

Cement lines. These are seen in connection with the surface epithelium of all the collecting ducts-primary, interlobular, intralobular. On the surface they outline the polygonal margins of the cells and at the various angles appear as dots. In longitudinal sections this cement substance forms a well defined point which projects some distance basalward between the cells sometimes half the length of the cell. As they near the base these intercellular cement structures become finer and are finally lost in the cell membrane (fig. 20). Fleischer failed to observe this characteristic of the cement lines in the lachrymal gland of the ox. Kolossow saw no cement lines in his studies on glands. Zimmermann, on the other hand, noted this peculiar.arrangement of the cement lines in the human lachrymal gland. $\mathrm{He}$ 
describes these cement structures as bands projecting down between the cell boundaries completely surrounding the proximal end of the cell, and states that this structure of the cement is peculiar to the lachrymal gland. I am inclined to think that the basal projecting intercellular cement lines are more or less limited to the angles of the hexagonal cell margins and that they do not form bands or caps surrounding each cell. They are always seen as intercellular continuations of the fine black dots seen at these angles. Cross sections of these ducts show their complete absence between many cells. This would not be the case if they formed true bands. The entire proximal half of the cells would appear in stained sections much darker than the basal half, which is not the case.

Intercalary ducts. These have been described by many histologists among whom may be named Schwalbe, Böhn and Davidoff, Merkel, and Henle. This duct has been compared to the Speichelröhren (Schaltstücke) of the salivary glands, especially the parotid. V. Ebner describes these ducts in the submaxillary gland as short blue tubes. Their deep staining characteristics have also been described by Merkel in the lachrymal gland of the dog; and by Nussbaum and Langley in the submaxillary of the rabbit. The latter also refers to the presence in them of 'large copious granules.' Zimmermann compares this duct in the lachrymal gland in man with the parotid gland. However, he saw no basal striations in the ducts. According to him the intercalary duct in man is not so well defined as that in the ox but the transition from the intralobular duct to the tubules is much more gradual. Merkel, in his observations on the lachrymal gland of the dog, also describes intercalary ducts but "fand hier keine Gänge mit Stäbchenepithlien." According to him these ducts stain more deeply than the other structures. Regarding the intercalary duct or schaltstücke, Fleischer states-"Die Form der Zellen, ihre einschichtigkeit, das enge Lumen, ihr häufiger plötzlicher Uebergang in die Ausführungsgänge entspricht ganz dem, was zuerst V. Ebner bei Speicheldrüsen als Schaltstücke bezeichnet hat. Sehr charakteristich. . . . ist auch ihre diffuse intensive Färbung." 
Secretion granules in the cells of the intercalary duct aredescribed by him. The chief characteristics then of the intercalary duct according to these observers are the more intense staining reaction and the presence of granules.

The deeper staining of these ducts is readily seen in sections of tissue fixed in the ordinary solutions and stained with iron haematoxylin and neutral stains.

For the study of the intercalary duct I found that the most interesting results were obtained from tissues fixed in Zenker's, embedded in celloidin, and stained in muchaematein. This stain was prepared and used according to Bensley's method

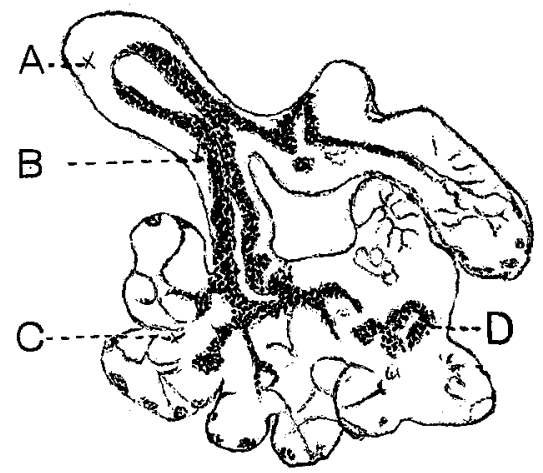

Fig. 11 Intercalary duct and tubules. Stipple board drawing projection. The granules of the intercalary duct are stained specifically with muchaematein, Tech. IV, 1. $A$, unstained intralobular duct; $B$, intercalary duct with granules; $C$, tubules; $D$, transitional cells.

(Technique IV, 1.) The sections were cut from $10-20 \mu$ thick. It was found that by following this technique the granules of the intercalary duct are stained specifically and definitely blue while the remaining tissue is unstained (fig. 11). This method therefore is of great value in the study of the intercalary duct and its relations to the intralobular duct on the one hand and the alveoli or tubules on the other. In the preparation of these sections it was found that after fixation in Zenker's the tissue should be thoroughly washed in order to remove as much of the salts as possible, for if iodine is used for this purpose the distinct granular stain cannot be obtained. Furthermore, 
if in thick sections the stain affects the tubules this can be removed by the use of acid alcohol. The time required to obtain the intense blue stain is brief, as less than one minute was necessary. Sections of the salivary gland and of the mucous membrane of the intestinal tract were used for controls. I found that the muchaematein stained the granules of the intercalary ducts of the lachrymal gland in the same time that was required to obtain a corresponding stain in the control sections. The similarity of this gland in its staining characteristics to the mucous glands and cells is interesting as it suggests the possibility of the presence of mucous secreting cells in the lachrymal gland. I shall discuss this phase later on. These muchaematein stained sections show the interlobular and the intralobular ducts unstained. The tubules generally take a light diffuse stain, and connecting the tubules with the intralobular ducts are the deep blue granular stained intercalary ducts - the stain is confined to the granules only.

The intercalary ducts vary greatly in length. The longest are from 200 to $250 \mu$ in length and the shortest are about 70 to $80 \mu$. The lumen of the intercalary duct is very narrow when contrasted with that of the other ducts. It averages about $6 \mu$ in diameter although much variation exists not only in its width in different ducts but also in a single duct. As a rule the lumen becomes wider as it approaches the intralobular duct. Primary intercalary ducts frequently give rise to a number of secondary branches which in turn terminate in one or more tubules. The cells of these ducts have an average height of $10 \mu$. The nuclei are not stained in muchaematein, they are seen, however, as large oval structures in the basal end of the cell. They never appear angular or compressed against the base. The granules are confined to that portion of the cell forming the lumen (the proximal end) and occupy about one half of the cell mass ( $\mathrm{fg} \mathrm{12}$ ). This arrangement of granules is rather constant, rarely is a cell seen where the granules extend to the base. They are proximal to the nuclei and in many cases obscure their rounded proximal surface. 
In cross sections of the intercalary duct the cells are pyramidal in form, the apices being in contact with the lumina which are seen to be very narrow when contrasted with the wide lumina of the intralobular and interlobular ducts. The lumina are formed as a rule by an average of seven triangular shaped cells. (These same cells in longitudinal sections appear cuboidal in form.) The granules are grouped in the apices of the cells and consequently these masses of granules are triangular on outline. A narrow

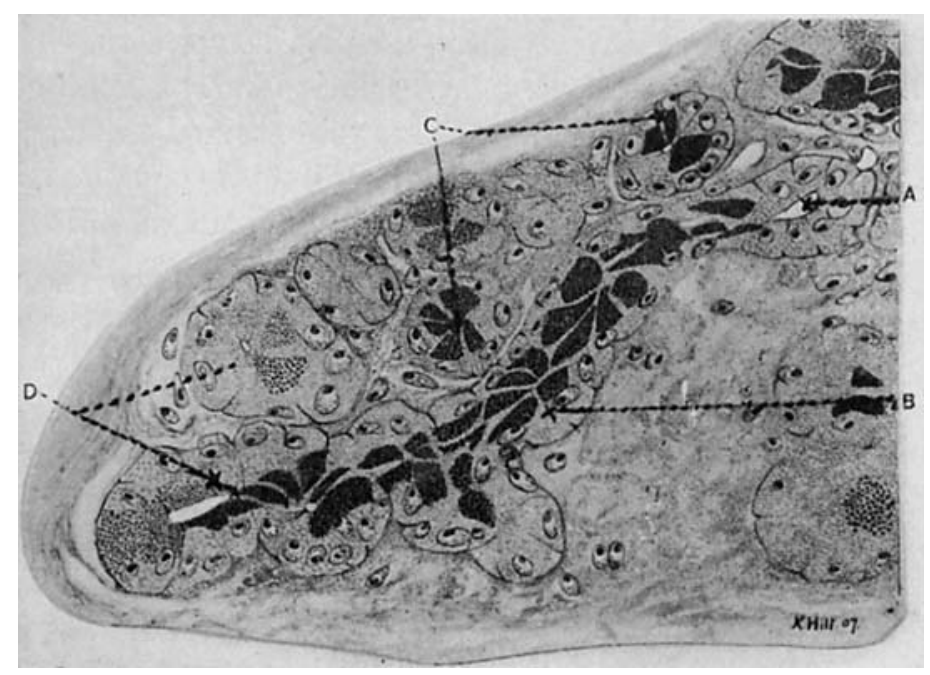

Fig. 12 Secretion granules in intercalary duct, Zenker's muchaematein. Zciss, oc. 4, obj. 8. Granules are specifically stained. $A$, intralobula duct; $B$, intercalary duct with granules; $C$, cross section of intercalary duct; $D$, tubules.

margin of unstained non-granular cell substance is seen between these granular masses and the cell membrane.

In longitudinal sections these cells appear cuboidal in form and rest on a well defined basal membrane which represents practically all of the supporting tissue.

Not all of the cells of the intercalary duct are stained by the muchaematein. Many cells are present which possess no granules and consequently are not stained. Occasionally ducts are seen in which in longitudinal sections the majority of cells of one side show no granular stain while the cells of the other side possess the 
characteristic granular stain. The presence of nongranular cells in the intercalary duct is plainly seen in cross sections of those ducts, the number of unstained cells varying in different sections. In some ducts only one cell may be present which does not possess the muchaematein stained granules, again such ducts are seen where the majority of the cells in cross sections are not stained. As a rule, however, most of these cells possess specifically stained granules.

At the origin of the intercalary ducts from the intralobular ducts the granules as a rule make their appearance in the first cells as a narrow layer in the lumen surface of the cell, having the appearance of a theca or cuticula. As the distance from the intralobular duct increases this stratum of granules widens until it occupies the entire proximal half of the cell. The complete transition from the normal amount to the complete disappearance of granules takes place in from four to seven cells. Frequently one sees an abrupt transition at the junction of the intercalary and intralobular ducts. In this type the granules in the cells of the intercalary duct remain normal and constant in quantity until the intralobular duct is reached when they disappear completely. Thus two neighboring cells may be seen one belonging to the intercalary duct and having the characteristic granules occupying the proximal half of the cell while the bordering cell belonging to the intralobular duct possesses no granules whatsoever. The granules in the intercalary duct are seen to extend to the tubules. They are readily seen in sections prepared by Weigert's method (Zenker's fixation) for the demonstration of elastic fibres. In the alcohol osmic bichromate, and methyl green anilin fuchsin preparation, the granules are well preserved and stain green.

Tubules. The cells of terminal tubules vary in size and form depending upon the stage of secretion they are in. Thus they may be columnar, cuboidal, oval, polyhedral, pyramidal, spherical, or flattened. When the cells composing these elements are in the height of the granular stage the cells are large and bulging and the secreting end may then appear as an alveolus or acinus. Again when the cells are observed in a partial granular stage 
they are smaller and more cuboidal and the secreting end has a tubular form. This doubtless explains in a large measure the controversy regarding the structure of the secretiug terminalswhether tubules or acini. The finer structure of the cells of tubules is considered in the Section on granules.

\section{SECRETION GRANULES}

\section{Serous cells ${ }^{1}$}

For some time there was much discussion as to whether the granules seen in fixed preparations of glands were natural or the product of fixation. A. Fischer ('99) regarded them as artefactsFällungsprodukte. E. Müller, ('96) on the other hand, found that certain granules seen in fresh cells became more distinct when fixed with sublimate solution. The process of fixation was directly observed through the microscope. Held ('99) and many others have substantiated Müller's observations, and now secretion granules are no longer regarded as artefacts. Milawsky and Smirnow ('93) studied, in the parotid and submaxillary glands of dogs, the secretory changes resulting from electrical stimulation of the cerebral and sympathetic nerves supplying these glands.

Bensley ('96) among others (see his various papers for bibliography) has contributed much to our knowlege of the antecedent substance which goes to make up the granules of serous cells. He has observed that

During digestion a substance similar in chemical properties to the chromatin of the nucleus makes its appearance in the outer clear zone of the chief cells of the fundus glands. This substance, which may be called prozymogen, stains deeply and readily in haematoxylin, and presents a characteristic fibrillated appearance. (He suggests that in some cells this is dissolved in the nuclear substance and that sometimes it is collected in masses--plasmosomata.) During rest this proxymogen is used in some way giving rise to zymogen granules.

Speaking of the chief cells he states that the fibrillae in the outer zones of the cells are not so regular or distinct as in the

'Metzner ('07) in Nagel's Handbuch der Physiologie des Menschen gives an excellent discussion of secretion granules in general. 
salivary ducts and that they remind one of the nebenkerne in the pancreatic cells of the amphibians as described by Macallum, Erberth, and Müller. In a later contribution ('08) he suggests the probability of serous cells being made up of various groups. By using the following technique (1) examination of fresh material in blood serum, teased preparations or sections cut with Valentine knife, (2) experimental fixation, by which a fixative medium was obtained which would preserve the secretion antecedents in a form which is present in living cell, (3) differential microchemical staining, Bensley has obtained results "which seem to justify the subdivision of the serous class of cells into a number of subordinate groups" such as (1) 'tropochrome cells' which stain metachromatically under certain fixations and stains, and (2) 'homochrome cells' which do not stain metachromatically and in all liklihood form a heterogeneous group. In a still later contribution ('11) he speaks of prozymogen granules "zymogen granules in process of formation. . . .. These must not be confused with the basophile substance of the cell which has elsewhere been called 'prozymogen' by Macallum and myself." These prozymogen granules stain deeply in neutral red when used as a vital stain.

\section{Mucous cells}

Regarding the main differences between mucous and serous cells as revealed by more perfect fixations and staining processes, Bensley's ('03) conclusions may well be inserted here. The following reasons are given for his conclusion that the cells of the glands of Brunner, in eighteen out of nineteen genera examined, are of the pure mucous type-(1) granules (droplets?) have a low refractile index which corresponds closely to the mounting media; (2) no basal filaments, 'prozymogen,' in fixed preparations (the microchemical test for organic iron shows only relatively small amount of cytoplasmic nucleoproteid); (3) the granules do not stain in iron haematoxylin or neutral gentian; (4) mucous cell stain in mucicarmin and muchaematein; (5) granules are soluble in weak alkaline solutions, insoluble in 5 per cent solution of hydrochloric acid and in artificial gastric 
juice containing 0.2 per cent of hydrochloric acid; (6) structure of cells. However "It is obvious that no absolute proof of the mucous character of the glands of Brunner can be brought forward until a positive microchemical test for the various mucins is devised." He suggests that mucous glands may contain small amounts of ferment. See also Bensley's ('02) summary of results in the histology of cardiac glands.

Similarities of mucous and serous cells

Regarding serous and mucous cells investigators agree that in both types the process of secretion is very similar and that the secretory substance is present in the form of very small globules generally termed granules. These granules are seen in fresh tissues with a few exceptions. They vary in size and in degree of light refractibility. The small granules have a greater refractive index than do the larger ones. In the case of the latter this index may be very nearly the same as that of the mounting medium so that they appear very dim, 'matte,' or can not be seen at all-this is truealso of the granules of certain cells throughout their secretory activity. In the resting cell before secretion has begun the cell is full of granules, and the nucleus which may appear flattened or angular lies at the base of the cell. After stimulation the granules are greatly decreased or disappear, the nucleus becomes round or oval and approaches the center of the cell. In most instances these granules can be fixed and stained. Usually the smaller ones stain more intensely than do the larger. In many glands the larger granules disappear in the process of fixation and an intergranular protoplasm remains.

\section{Granules in lachrymal gland}

\section{According to Langley (lachrymal gland of the rabbit) -}

In the resting gland the alveoli are throughout unevenly stained. The nucleus is irregular and lies in the peripheral portion of the cell. During activity the outer portion of each alveolus begins to stain evenly at first without much alteration in the nuclei or in the inner portions of the cells, later the nuclei become larger and travel towards 
the center of the cells, they are then much less distinct, at the same time the lumen becomes more obvious.

The observations of Reichel, Kolossow, and Lor were also confined to the secretory changes. Puglisi-Allegra ('04) contributes an extensive article.

Studio della glandola lagrimale. . . . In una glandola normalmente funzionante si possona distinguere due specie de cellule.

Dopo una eccitazione prolungata è facile notare numerose cellule piuttosta piccole con protoplasma oscura è fortemente granuloso, totalmente prive di secrezione.

Nicolas saw numerous granules in the lachrymal gland of man after fixation in sublimate or Flemming's solution and staining with aniline-safranin, Biondi-Ehrlich and Altmann's methods.

Noll saw in the nonstimulated fresh lachrymal gland of the cat "die meisten Zellen deutlich granulirt. Die Cellgrenzen treten nicht immer gut hervor." The nucleus-"der Basis nahe gelegen, als rund oder ovalen." According to him these granules had remarkable differences of refractibility; they disappeared when water was drawn under the cover-glass and reappeared when 2 per cent $\mathrm{NaCl}$ was added; other cells were seen with no apparent granules except numerous 'Protoplasmakörnchen (these cells he termed 'matte Zellen'); the tissue when fixed and stained by Altmann's method showed faintly and deeply stained cells - "hellere und dunklere Zellen." Transitional cells were also seen which showed both the characteristics of faintly stained and deeply stained cells. Noll fixed fresh tissue with Altmann's fluid and observed the process by means of the microscope. The strongly refracting granules in fresh tissue became the deeply stained granules in prepared sections while the less refracting ('matteren') granules became the faintly staining cells with the network. In the latter case the granules were not conserved but only meshes remained. The deeply and faintly staining cells then represent different stages in the secretory activities of the gland, the latter representing the higher stage of granule formation. After electrical stimulation fresh tissue showed "das die Alveolen bei Weiten nicht so viel GranulaZellen enthalten. In der Hauptsache sieht man Zellen mit 
matter Grundsubstanz." The nuclei were round, granules were present in the neighborhood of the nuclei.

Fleischer, in the lachrymal gland of the ox, describes peculiar granular forms-ring, crescent, or demilune granules-which had previously been observed by M. Heidenhain ('90) (See other references to him in Bibliography), Nicolas, and Held. Held, in the submaxillary gland of the rabbit, saw this crescent or ringlike type in addition to the highly and slightly refracting granules. Nicolas failed to observe them in the parotid gland. Heidenhain describes these Halbmondkörperchen in the accessory sex glands of the Triton. The tissue was taken during the heat period. . According to him these demilune granules represent a phase in the secretion of the cell; they are formed from small structureless primary granules, and in turn pass into large round secondary granules which are excreted from the cell. Fleischer found these types of granules in the lachrymal gland of the ox. In sections fixed in 10 per cent trichloracetic acid or picric acid with brillantschwarz-toluidin-blausafranin, he describes (1) round deeply stained small granules, (2) granules of the same size and form which take on a much lighter stain (3) granules with two zones, a dark crescent shaped cap (kapuze) which partly surrounds a lighter stained trager, (5) oval forms of the type just named, (6) granules in the form of crescents or demilunes without any indications of a trager or lighter stained area, (7) granules with ringlike borders surrounding a lighter stained center. These various types were seen without any special arrangement or distribution. Some cells possessed only the deeply stained round forms, others contained only the demilunes, and others again were seen in which all the various forms were present. Fleischer verified his observations by at least four different kinds of fixations in order to escape the possibilities of artifacts. He saw also these variously formed granules in the fresh gland. Hence he was positive of their presence. No Halbmondformen granules were seen in the parotid or submaxillary gland of the calf.

Granules in Fresh Tissue. My observations show that granules are readily seen in all fresh lachrymal gland tissue when 
mounted in either serum or physiological salt solution. The refractive index of these granules is much greater than that of the mounting media and consequently the granules stand out clearly. In the great majority of tissues examined, practically all cells of both the tubules and the intercalary ducts appear to possess granules. Only rarely are any of these cells seen free from granules. This condition is due to the fact that the few granule-free cells are masked by granular cells which may be above or below them as it is impossible to procure fresh tissue sections one cell layer thick. Fresh lachrymal gland tissue consequently appears as a rule to be in an extremely granular stage. It is possible, however, after examinations of numerous glands to make out several phases in the secretory activities of glands although this is much better seen in permanent preparations. These various phases observed in fresh tissue mounted in ox serum may be generally classified into three groups or types. However, every gradation exists between these groups.

A. The first type may be termed the granular stage-in the height of granule formation. All cells of both tubules and intercalary ducts are filled with granules. The alveolus or tubule is easily recognized surrounded by the basal membrane and interstitial tissue. The cell boundaries are readily seen. The majority of cells forming the tubules are completely filled with secretory granules. Consequently no clear basal zone is present as is the case in the pancreas. These granules extend from the base of the cell to the summit. So numerous are they that most cells appear to bulge and as a consequence no lumina are seen. These granules obscure for the most part the nucleus of the cell. In many cells, however, the distal half of the nucleus can be seen lying on the base of the cell. The granules vary in size from almost imperceptibly fine structures to granules several micra in diameter. They vary also in their powers of light refractivity-the smaller ones refract light to a much greater degree than do the larger. There is no regularity in the distribution of large and small granules within the cell. They are scattered throughout the cell, appearing at both the base and the summit. Frequently large granules are seen which have 
dark ring-like contours. This phenomenon is undoubtedly due to variations in the refraction of light as it passes through the granules and does not represent any peculiar constituent of the granules as held by Fleischer.

The granules in the intercalary duct show the same characteristics as do those of the tubules so far as size and the powers of refraction are concerned.

B. In the second group or type of fresh glands examined, one sees considerable variation in the form and size of the cells of the tubules as well as in the quantity of granules-large bulging cells described under $A$ and smaller cells which have various forms (irregularly cylindrical, pyramidal, or appearing as demilunes wedged in between the bulging cells). These smaller cells may be filled with granules or may possess but few. Their nuclei are always round or oval and are separated from the base of the cell by a narrow zone of cytoplasm.

C. Glands are occasionally seen in which the tubules for the most part are made up of cells which are regular in form--low cylindrical, pyramidal or cuboidal in outline. The granules are confined to the proximal half of the cells. The nuclei are round and oval and do not touch the bases. The lumina of the tubules are wide and open. This condition represents a stage of partial exhaustion of granules.

At the margin of these fresh tissue preparations, cells are seen which have been ruptured by teasing, cutting, etc. Here the granules are seen passing from these cells into the serum and still retaining the same continuity as they possessed within the cell. In fact the entire margin of the tissue is characterized by the presence of these free granules. In order to exclude the possibility of the more finely formed elements in the blood being responsible for this loose granular mass the serum was carefully filtered before using as a mounting medium. Microscopic examination of the serum, after filtering, revealed no such formed elements.

When sections of fresh tissue are mounted in physiological salt solution, the cells show the same characteristics as those described for the serum mounted tissue. The loose granules 
do not preserve their continuity as long, however, in the salt solution as in the serum.

Fresh tissues mounted in distilled water soon lose (in five minutes) their granules. As a consequence the nuclei which are round or oval become very prominent. They are seen for the most part in the basal portion of the cells and are opaque and homogeneous. No nuclear granules are seen. In no instance are the nuclei seen to be angular and flattened as in many fixed and stained preparations. They have in all likelihood taken up enough water to be swollen when observed under these conditions. The water is absorbed before the granules have sufficiently disappeared for the process to be observed. If 2 per cent salt solution is drawn under the slide after the granules have disappeared in distilled water they reappear again. This phenomenon was observed by Noll in the lachrymal gland of the cat and by Langley and others in other serous glands.

When fresh tissues are mounted in five per cent solution of hydrochloric acid or sodium bicarbonate the granules become indistinct-disappearing much more rapidly in the former solution than in the latter. An intracellular network remains after treatment with these solutions, the meshes of which were formerly occupied by the granules. This net work should be interpreted in the sense of Bensley "optical sections of the continuous cytoplasmic partitions which separate the granule holding spaces from one another."

Thin sections of fresh lachrymal gland were mounted in the following vital stains in physiological salt solution with these results:

1) naphthol blue-granules stained a purplish blue.

2) neutral red-granules were very faintly stained. I did not observe here prozymogen granules more deeply stained as observed by Bensley in the pancreas of the guinea pig.

3) janus green-the mitochondrial elements were stained. This will be discussed under that caption.

4) trypan blue $-\mathrm{a}$ diffuse light blue stain, granules only faintly stained. 
5) isamin blue-a very faint blue stain limited chiefly to the interstitial tissue. Certain cells in the alveolus also appeared more deeply stained than did others.

6) trypan red-a diffuse light red stain.

7) sulforhodamin - -a diffuse faint light red stain.

8) pyronin-intercellular canals and lumena of ducts stained.

Granules in fixed and stained preparations. Zenker's. Attention has already been called to the fact that the granules of the intercalary duct when fixed in Zenker's solution stain deeply in muchaematein and mucucarmin while the other granule stains do not affect them. The tubules, on the other hand, show no deeply stained granules but appear under low power only diffusely and faintly stained. Careful examination of these tubules with the oil emersion, however, shows various intensities of staining reactions on the part of the cells--which may be generally classed as follows: a) Large rounded bulging cells as seen in the fresh sections. Here a faintly stained cytoplasmic network is seen throughout the cell. The meshes of this network are round and appear to hold large unstained granules. The nucleus is angular or flattened and lies against the base of the cell. In fresh tissues the granules of these cells are distinctly seen and the intergranular network is not seen, while in Zenker's muchaematein preparations the granules are not stained but the intergranular network is distinctly seen. b) Cells more cylindrical in form frequently showing indented sides as if they had been pushed in by the round bulging cells (also seen in fresh preparations). They possess very faintly stained granules. The nuclei as a rule are round or oval. c) So called transitional cells. In the use of the term transitional cells reference is made to those cells that mark as a rule the junction of the intercalary duct and tubule. They possess granules similar in structure and staining reaction to those of the intercalary duct and are always preserved in Zenker's solution (figs. 11 and 12).

Bensley's solutions. For the fixation of granules in the tubules, it was necessary to use other solutions than Zenker's. The granules in tubules are best preserved by Bensley's sublimate 
alcohol bichromate solution (Technique IV, 2 a) and by formalin bichromate sublimate solution (Technique IV, 2 c). Tissues must be small as the penetration of these solutions is not great. In these solutions the granules of both the tubules and the intercalary ducts are preserved. These are readily stained with muchaematein (Technique V, 1), mucicarmin (Technique V, 2) iron haematoxylin, iron haematoxylin counterstained with mucicarmin, copper chrome haematoxylin (Technique $V, 5$ ) neutral gentian (Technique $V, 6$ ) and safranin-acid violet (Technique $\mathrm{V}, 7)$.

Mucous stains. Sections fixed in Bensley's sublimate alcohol bichromate solution or in formalin bichromate sublimate solution when stained with muchaematein or mucicarmin show that the selective staining is confined entirely to the granules of the tubules and ducts. The various types of cells as seen in these sections depend upon the secretory state of the gland at the time of fixation. The various stages described in the tubules of fresh tissue are seen in these preparations and may be grouped as follows:

(1) Large rounded or bulging cells completely filled with intensely blue stained granules-type 1. All other structures within these cells are obscured as a rule. Frequently, however, flattened nuclei are seen at the base. These cells correspond to those described in both fresh tissues and in Zenker's muchaematein sections. In the latter case the granules were not stained but the intergranular network was prominent as a consequence of a light blue stain.

(2) and (3) Cells more or less cylindrical or pyramidal in outline, or appearing as demilunes in the periphery of the tubules completely shut off from the lumen by the large bulging cellsfrequently the cylindrical cells are constricted in their vertical axis by the pressure of the bulging cells and thus simulate in outline hour glasses. The nucleus is generally round or oval and does not lie directly on the base of the cell but is separated from it by a narrow zone of cytoplasm. These cells can be divided into two classes. The one contains relatively few or, rarely, no granules. The granules are seen in the proximal end of the 
cell or throughout the cytoplasm and stain with different degrees of intensity-many are but faintly stained. These will be referred to as type 2. The cells of the other group (type 3) are similar to those of type 2 in form but are full of deeply stained granules.

Generally there is no regularity of distribution of these various types. Tubules are seen wherein all the cells composing them are of the first type. Others are seen made up of all three types.

Occasionally glands are obtained wherein practically all the cells within the tubules are cuboidal in form and show the granules proximal to the nuclei as described under fresh tissue (Fresh tissue C). Here the cells are not large or bulging and the lumina are open.

In other sections, which are rare, one sees numerous granules with deeply stained rings around them. These were described by Fleischer who considered them as a stage in lachrymal secretion. I do not think such is the case, however (see Discussion of granules.)

The cells of the intercalary duct show the same characteristics as those described in Zenker's celloidin preparations.

Iron haematoxylin. In iron haematoxylin stained sections one sees the same types of cells described under the mucous stains. The large bulging type 1 cells are filled with black granules of various sizes, the nuclei angular or flattened against the bases of the cells. The type 2 cells have grayish granules and their round or oval nuclei show as a rule one or two large chromatin masses. The type 3 cells are filled with deeply stained granules or a mixture of both black and gray granules.

The different intensities of the staining reaction on the part of granules is a striking feature of the tubules. ' Large and small granules may be seen side by side in the cell some staining deeply black while others are gray or faintly stained. The granules of the intercalary duct vary also in the intensities of staining reactions but not to such a degree as those of the tubules.

Iron haematoxylin and mucicarmin. Sections stained with iron haematoxylin and counterstained with mucicarmin show some very interesting features. All the granules of certain 
cells stain red in mucicarmin and all the granules in other cells stain black in iron haematoxylin while in still others both red and black granules are seen in the same cell (fig. 13.)

Copper chrome haematoxylin. Sections stained in copper chrome haematoxylin show the granules to be deeply stained. The cells are readily classified into the three types already described. The large bulging cells are filled with black stained granules of various sizes. The granules in the type 2 cells are very lightly stained - in many they are so faintly stained that

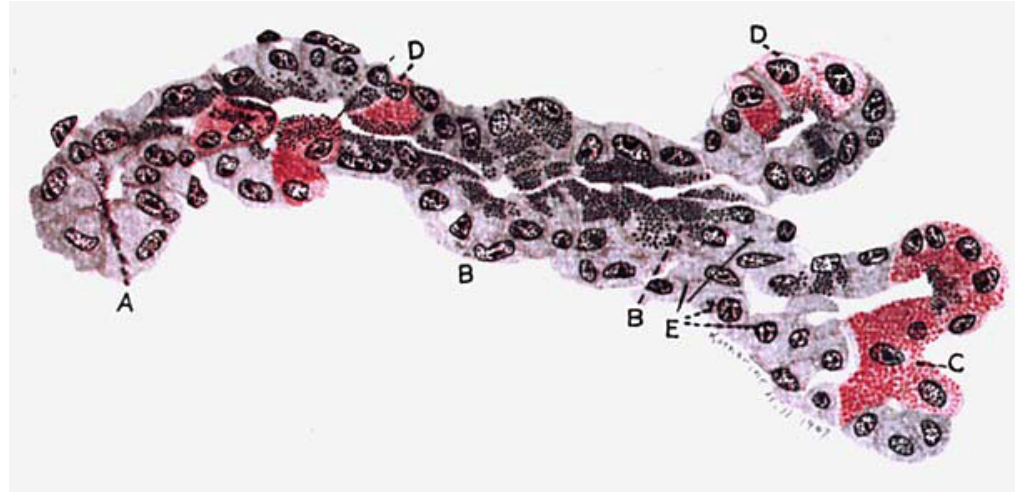

13

Fig. 13 Secretion cells with granules, Tech. IV, 2, a ; V. 4. Leitz, oc. 2, obj. $1_{1:}^{1}$ oil. $A$, intralobular duct; $B$, cells possessing granules all of which stain black with iron haematoxylin; $C$, cells with the entire granular content stained red with mucicarmin $D$, cell with granules some of which are stained with iron hamatoxylin and others with mucicarmin; $E$. secretory cells with no granules.

it is difficult to make out any granules whatsoever. The type 3 cells are filled with black granules.

Sections fixed in the sublimate alcohol bichromate solution and stained in copper chrome haematoxylin show, in the larger ducts, mitochondria either as irregularly distributed granules or as filaments (see Mitochondria.)

Neutral gentian and safranin-acid violet. These proved to be excellent stains for granules in the lachrymal gland. Tissues fixed in either the sublimate alcohol bichromate or the formalin bichromate sublimate solution show the characteristics already 
described. In fresh safranin-acid violet the nuclei stain red while the granules stain a dark greenish blue. The advantage of this stain lies in this contrast. In the large bulging cells the red flattened basal nuclei are generally seen while in the other stained cells they are made out with difficulty since the colors of nuclei and granules are similar.

The granules in the cells of the intercalary duct stain similarly to those of the tubules. Lumina are always seen but vary in diameter. The cells are generally uniform in size and shape. No bulging cells are seen. In each cell there is a narrow zone of non-granular cytoplasm surrounding the granules. No variations are seen in the size, shape, and position of the nuclei whether the cell contains the maximum of granules, only a narrow zone at the proximal end, or no granules whatsoever. They are similar in structure and staining characteristics: to the round and oval nuclei seen in the tubules.

In thin sections stained with neutral gentian the outer layer of cells surrounding the secretory cells of the intercalary duct are readily made out. Near the origin of the duct these cells are still more or less cuboidal but towards the tubular end the cells with their nuclei become more and more elongated. These cells stain more faintly than do those of the inner layer. They surround the tubule as elongated cells between the secreting elements and the basal membrane (see Connective Tissue.)

As in the case of the iron haematoxylin stained sections one is especially struck by the various intensities which these granules stain with neutral gentian and safranin-acid violet. In well fixed tissues the majority of granules stain deeply in both of these dyes. However, one frequently sees in the same cell, in both the tubules and the intercalary ducts, granules lying in close proximity to each other some of which are stained deeply blue, others only faintly yellow or brown, and still others barely stained at all. This variation in intensity of staining is in no way related to the position of the granule or its size. Cells are frequently seen bordering each other, one possessing deeply stained blue granules throughout, the other possessing yellowish brown or faintly stained granules. The probable expla- 
nation of this phenomenon is, as suggested by Bensley- "the granule substance has a primary difference of density due to difference in water content or a change in dispersion grade of the colloid." Certainly some granules retain the stains much more tenaciously than do others. I have not observed these extreme variations in the staining reaction of granules in other glands such as the pancreas and submaxillary.

The secretion granules of the lachrymal gland are not stained in neutral red or in any other of the vital stains employed.

I saw no free granules in the lumina of either the tubules or the ducts. Frequently such appears to be the case however, for one sees, especially in the intercalary duct, elongated groups of granules which seem to be in the lumen. Careful study, however, reveals the fact that these granules mark the proximal end of the other cells which contribute to the formation of the lumen.

No cuticle, striated or otherwise, was observed in the epithelium.

\section{Discussion of granules}

Secretory changes in cells. Unfortunately the lachrymal gland of the ox does not lend itself for experimental study of a stage of rest, a stage of activity, and a stage of exhaustion. Studies based upon microscopic changes in the cells as induced by rest and stimulation must be accomplished in the more accessible laboratory animals. My study of granules was based chiefly on the methods of their conservation and their staining characteristics. However, a sufficient number of glands was examined to gain some light upon the changes that do occur in the normal secretory activity of the gland. According to the tissues fixed in Bensley's sublimate alcohol bichromate solution and in formalin bichromate solution supplemented by a study of fresh tissues the secretory phases of the gland may be classified as follows:

A. A maximum granular stage in which most of the cells of the tubules and intercalary ducts are filled with granules. The majority of cells in the tubules belong to those described as type 
1 under the various stains - completely filled with granules and bulging, lumina of the tubules not visible.

B. A medium granular stage in which the tubule possesses for the most part cells of the types described as types 2 and 3 . Rarely does one find an entire tubule made up of these types alone, as bulging cells of type 1 are generally present. It will be recalled that type 3 cells are those described as cylindrical, pyramidal, or crescent cells filled with deeply stained granules. The nuclei of these cells are still round or oval and separated from the base of the cell. This type doubtless represents an earlier phase to that of type 1 in the stage of granule formation. Granules have formed in sufficient quantities to fill the cells but not to such an extent as to enlarge them-cause them to bulge.

Cells described as type 2 in all likelihood represent two phases in secretion. a) Those which possess few granules at their proximal ends suggest the terminal phase of secretion wherein the granules for the most part have passed out of the cells. b) Those in which comparatively few granules are seen scattered throughout the cells suggest cells in the beginning phase of granule formation. These granules stain with varying intensities. Some are large and pale, others small. There is no regularity to their distribution. The few nongranular cells may be interpreted as occupying a position between the terminal of granule expulsion and the beginning of the formation of new granules. The very few nongranule cells seen and the fact that the type 2 cells usually possess granules both at the lumen end of the cell (terminal secretion) and also a few granules throughout the cytoplasm (beginning granule formation) strongly suggest that the extrusion of granules and the new formation of granules go hand in hand in the same cell during the normal secretory activity of the gland. We have then in this gland a continual secretion as indicated by the cells showing all phases of secretory activity.

C. In the third group of glands the secreting cells were much reduced in size, the lumina wide and open, the few granules present confined to the proximal end of the cell, and the nuclei round and oval. This condition was uniform throughout the gland and simulated preparations obtained by other observers 
after stimulation with pilocarpin. In my opinion these glands represent a condition of intense secretion before the animals were killed. Many factors could be responsible for this excessive activity.

The results of my study of the various phases of secretion agree in a general way with those of other observers. Detailed study of the cellular changes during secretory activity, must be, as stated, on the laboratory animals. Preliminary work on certain species of Anura and Urodela gives much promise, and I trust that a paper will soon appear on this subject. In the lachrymal glands of the ox I have failed to observe the secretory elements of the cell divided into two zones by a strand of reticular protoplasm stretching across the cells as noted by Bensley ('02) in the cardiac glands of mammals and in the glands of Brunner (Bensley '03). Nor was an intermediate stage present as is seen in the Pancreas (Bensley, (11) which contained small granules (prozymogen granules) that stain with neutral red, intra vitam.

I have failed to observe the paranucleus described for secreting cells, including the lachrymal gland, by Gaule, Ogata, Nussbaum, Garnier, and others. As stated elsewhere, the three zones described by Zimmermann were not observed. No definite light has been thrown as a consequence of this study upon the origin of these granules. They seem to make their appearance anywhere within the cytoplasm, independent of position or of any marked demonstrable antecedents such as a basophil substance (toludin blue), iron possessing substance (Macallum reaction), or prozymogen (Bensley's vital neutral red). Exception to this statement should be made if we are to consider mitochondria as an intermediate substance. This will be discussed under mitochondria. Perhaps the presence of such antecedents should not be anticipated, as the lachrymal gland possesses so far as I know no demonstrable specific enzyme. Whether the nucleus plays any part in the formation of granules, I am unable to say. It is true that in the tubules when in a stage of maximum granule formation (cell type 1), the nucleus is more or less flattened and compressed against the base while 
in cell types 2 and 3 it is round or oval and separated from the base of the cell by a narrow zone of cytoplasm. However, no distinct changes are seen in the chromatin. In both instances one or frequently two large chromatin masses are surrounded by numerous finer granules of chromatin. The change of position and form of the nucleus may be due entirely to the quantity of granules. The nucleus of the intercalary duct, on the other hand, shows no appreciable change in form or position whether the cell is at its maximum stage of granule formation or its minimum.

The fixation and.staining of granules. When the tissues are properly fixed in either Bensley's solution or formalin bichloride bichromate solution all granules are conserved. Such is not the case when alcohol, Zenker's or numerous other fixatives are used. Zenker's and Altmann's fix the granules in the intercalary duct and frequently in some few cells in the tubules. The granules in the large bulging cells are not preserved in alcohol, Altmann's, or Zenker's but, instead, the intergranular network remains.

Neutral gentian, safranin acid violet, copper chrome haematoxylin, iron haematoxylin, muchaematein, and mucicarmin proved to be the most satisfactory stains for the granules.

Are secretory cells of tubules similar in function? Notwithstanding the variable staining reactions on the part of granules and the various sizes and shapes of cells, cells of the tubules are doubtless similar in function. We have no evidence that more than one functional type of cell is present. Proof of this is seen in the granular stage when all the cells of the tubules stain similarly. Furthermore other structures in these cells are alike so far as I have been able to make out. The changes in position and form of the nuclei only represent different secretory phases.

Staining reaction of granules, selective action. In order to prove that the cells in both the tubules and the intercalary ducts are capable of taking various granular stains, serial sections three micra thick were cut and fastened to different slidesone section for each slide. The first section was stained with neutral gentian, the second with muchaematein, the third with 
iron haematoxylin, the fourth with mucicarmin, and so on until all the granule stains were used. It was found that all granules in these sections were stained with the various dyes. This demonstrated that the granules of the same tubule and intercalary duct are capable of taking various stains. Furthermore the same granule is apparently capable of taking any one of these stains. This is shown in the counter staining. When sections stained in either iron haematoxylin or copper chrome haematoxylin are differentiated to such an extent that the granules are pale, then stained with mucicarmin they appear red. This condition is further substantiated by sections from those rare tissues which contain the peculiar ring-like or crescent granules. In many of these granules the caps or crescents and the rings stain black in iron haematoxylin while the bodies of the granules stain red after counterstaining in mucicarmin. That many granules, however, show an affinity for certain stains seems very probable, as cells are present in the tubules and intercalary ducts the entire granular contents of which stain black with the iron haematoxylin while all the granules of the neighboring cells stain red after counterstaining with mucicarmin, and again a mixed condition of red and black granules is seen in other cells. However, the distribution of these red and black granules within one cell as well as the distribution of cells containing either all black or all red granules in the tubules and intercalary ducts is very irregular and the ratio of these cells to each other is very inconstant.

Various explanations for this selective action on the part of some granules for iron haematoxylin, others for mucicarmin may be advanced as follows:

1) The granules at different stages of their development have different selective action for various stains. Against this view, however, is the fact that this selective action on the part of granules bears no relation to their size or distribution in the cell. Large and small granules, either at base or summit, may take one or the other stain. The large bulging granular cells of the tubules seem to have a greater affinity for mucicarmin, however, many exceptions to this observation were noted. 
2) Even the granules within one cell may be subdivided into a number of groups, each group representing a specific chemical structure and contributing some element to the sum total of secretion. If such be the case one may readily assume a selective action on the part of each group for specific stains. Of course we have no proof for such an assertion.

3) A possible explanation lies in the fact that in the differentiation of sections stained in either iron haematoxylin or copper chrome haematoxylin some granules hold these stains much more tenaciously than do others. This may be due to varying degrees of fixation of the granules. It is the faintly stained granules, those differentiated most, that are stained again in mucicarmin. This observation had been made.

However, as Bensley has pointed out:

The difficulty of all these discussions of the different staining properties of granules in the same cell arises from our ignorance of the changes which would be produced in the absorptive properties of these colloids with variations in their water content and so in their dispersion grade. The dyes which we use for this staining are all dyes which may be absorbed. I think under the circumstances it would be rash to assume a difference in the fundamental composition of the granules on the basis of the different staining.

Are the cells of the tubules and intercalary ducts of the same functional type? Attention has been called to the fact that the intercalary duct stains more deeply in the ordinary dyes than do the tubules (v. Ebner, Nussbaum, and Langley, submaxillary gland; Merkel and Fleischer, lachrymal gland). Fleischer concludes that this duct has a specific secretion differing from that of the tubules. He gives as his reason the presence of such large granules.

I too have observed that the intercalary duct as a rule stains more deeply in the ordinary dyes. This can be readily explained by the fact that the cells are smaller and more compact and that the granules are conserved in such general fixatives as Zenker's solution, while in the majority of cells of the tubules the granules are not fixed but an intergranular cytoplasmic network remains. 
Fleischer holds that a specific secretion is produced in the intercalary duct:

Das vorhandensein derartiger grosser Granula in den Schaltstückzellen, wie ich sie auch in der Thränendrüse gefunden habe, spricht mit grosser Wahrscheinlichkeit für eine besondere sekretorische Bedeutung dieser Zellen und zwar muss es sich um eine andere Art von Sekret handeln, als dasjenige, das die Zellen der End-abschnitte auscheidet.

While I found that the granules in the cells of the tubules-cell type (1) -in well fixed preparations are as large or even larger than those in the intercalary ducts, still certain marked differences do exist between the cells of the intercalary duct and the tubules. The granules in the intercalary ducts are fixed in Zenker's solution while those of the tubules are for the most part not preserved in this solution. When fixed in this solution the granules of the intercalary ducts stain deeply and readily in mucicarmin and muchaematein while the other granule dyes do not affect them. In tissues fixed in Bensley's acetic, bichromate osmic solution and stained with anilin fuchsin-methylgreen these granules are stained green while they are not preserved in the bulging cells of the tubules.

A narrow band of non-granular cytoplasm is always seen between the cell membrane and the granules. The granules never reach the base of the cells. The cells do not undergo any marked variation in size or shape during their secretory activity. The nuclei remain practically constant in form and position whether the cells are empty or possess numerous granules. No secretory capillaries are present. Frequently, however, intercellular indentations are seen. These are some of the features that characterize the cells of the intercalary duct.

In the tubules, on the other hand, the granules in the majority of the cells are not fixed in Zenker's solution, only those that mark the transition from the duct to the tubule are fixed. The granules when fixed in the height of the secretory stage fill the entire cell and cause it to bulge out. Marked changes consequently appear in the form and position of the cell which is true also in the case of the nucleus. Secretion capillaries are also present. 
Nature of granules. Ellenberger states that the lachrymal gland of the pig is a mucous secreting gland, while Boll statesregarding pig, sheep, calf, and dog-"Es ist hieraus mit Sicherheit zu erschliessen dass das Secret der Thränendrüse nie mucin enthält." Which is true in the case of the lachrymal gland of the ox? Although the specific reaction of these granules to the mucous stains might indicate that this gland may be mucous in character, in my opinion it cannot be classed as mucous, since:

1) If one takes fresh pieces of the pancreas, submaxillary, and lachrymal glands and compares the secretions which can be pressed out one is impressed with the similarity of certain physical properties of the secretions of the pancreas and lachrymal glands. The fluids of both are thin and watery with no adhesive qualities. The secretion from the submaxillary gland, on the other hand, is viscid, thick and sticky to such an extent that pieces of tissue are readily supported by it. 2) A careful analysis of numerous lachrymal glands from the standpoint of their physiological chemical structure showed that they are in no wise similar to mucous glands. 3) The structure of the cells of the tubules and intercalary ducts does not simulate those of the submaxillary gland and other mucous glands. 4) One finds that the lachrymal gland has the following characteristics which are true of serous glands in general: a) The granules have a high refractive index. b) The granules are insoluble in weak alkaline solution. Following Bensley's procedure I found that sections fixed in his bichromate alcohol sublimate solution showed no change after having stood for twelve, twenty-four and forty-eight hours in 5 per cent potassium carbonate solution at a temperature of $38^{\circ}$, while in similarly treated sections of the submaxillary gland the granules of the mucous cells had completely disappeared in twenty-four hours. The granule stain in the lachrymal gland is as definite and as intense as is seen in the stained normal sections. Similarly treated sections in five per cent hydrochloric acid for the same length of time did not affect the granule stain in the least. c) The granules stain readily in all serous granule stains. d) The presence of secretory capillaries. On the other hand certain characteristics 
are present also which are generally true of mucous secreting cells: a) The flattened nucleus seen compressed against the base of the cell in the large bulging cells. b) The absence of basal striations as seen in many serous cells. c) The presence of but minute traces of prozymogen (toludin blue stain) and organic iron-- the latter demonstrated by Macallum's method d) The specific reaction to the mucous stains.

5) Examination of lachrymal secretion in the human shows only a small amount of mucin present which is readily accounted for by the presence of goblet cells both in the ducts and conjunctiva.

Analyses of human lachrymal secretions show:

\begin{tabular}{|c|c|c|c|c|}
\hline \multirow[b]{2}{*}{ Water. } & \multicolumn{2}{|c|}{ FRERICHS (46) } & \multirow{2}{*}{$\begin{array}{c}\text { ARLT LERCH } \\
\\
98.233\end{array}$} & \multirow{2}{*}{$\frac{\text { MAGAARD }(82)}{98.1200}$} \\
\hline & 99.06 & 98.70 & & \\
\hline Epithelium...... & 0.14 & 0.32 & & \\
\hline Albumin.... & 0.08 & 0.10 & 0.504 & 1.4638 \\
\hline Mucus and Fat... & 0.03 & 0.34 & Trace & \\
\hline Salt $\mathrm{NaCl} \ldots \ldots \ldots$ & & & & \\
\hline Phosphate.. & 0.43 & 0.54 & $1.257)$ & \\
\hline Other salts $\ldots \ldots \ldots \ldots \ldots \ldots$ & & & $0.016\}$ & 0.4160 \\
\hline
\end{tabular}

No positive proof can be advanced that these cells are either serous or mucous in character as we have no specific methods for determining this. The lachrymal gland may be considered as not highly specialized in function when compared with such glands as the pancreas. It appears to occupy an intermediate position between the more highly specialized serous and mucous glands and possesses many characteristics of both. My results plainly show that great care must be taken in determining the nature and function of glands from the standpoint of microchemical staining.

Rings and demilune granules. Attention has been called to the fact that these peculiarly shaped granules have been described by Held, Nicholas, and Heidenhain in other glands, and especially by Fleischer in the lachrymal gland of the ox, who described

2 Nagel's handbuch. 
them as being present in all lachrymal glands and stated that they represent constant and distinct phases in the evolution of the granule. My observations do not agree with those of Fleischer. While these peculiar forms of granules were seen occasionally in the numerous preparations of lachrymal gland which I made, their occurences were relatively so rare that they must be considered as exceptional. I have also seen these peculiar granules in the accessory lachrymal gland tissue of the third eyelid of the ox as well as in the orbital glands of frogs. Frequently ring granules are seen in fresh preparations of these glands, but the explanation lies in the effect that a large granule may have on light passing through it. Light may pass through the center of the granule with but little or no refraction while it may be greatly refracted at the contour. I think that these peculiar granule structures in fixed preparations can be explained from the standpoint of fixation. It is the large granules which show these peculiarities when present at all. It can be readily conceived that the surfaces of these granules may be acted upon more thoroughly by the fixing fluids than the centers and consequently stain more deeply. Small tissues well fixed in Bensley's solution or formalin bichromate sublimate solution seldom show these peculiar granule structures. It is difficult to conceive of these granules of fluid or semifluid consistency taking the form of rings, demilunes or crescents. Our knowledge of the physical properties of matter in such condition will not permit of such a conclusion.

\section{MITOCHONDRIA}

I found that lachrymal gland tissues prepared according to Bensley's method for the demonstration of mitochondriaacetic osmic bichromate, anilin fuchsin methyl green-show these elements very clearly.

Tubules. In the tubules two chief cell types are made out somewhat similar to those described by Noll in the lachrymal gland of the cat after fixing with Altmann's solution--light and dark cells. 
Light cells: The light cells correspond to the large bulging cells (type 1) heretofore described. The secretory granules are not preserved in this solution but an intergranular cytoplasmic network remains. The meshes, which originally" possessed granules, now appear empty. This condition is seen also in tissues fixed in Zenker's solution. Irregularly distributed throughout this dark stained cytoplasmic network are seen these minute fuchsinophil granules or mitochondria. The majority are slightly elongated simulating somewhat bacilli. Others again are round, cocci like. They are seen in every portion of the cell from the base to the summit. (fig. 14). In no instance

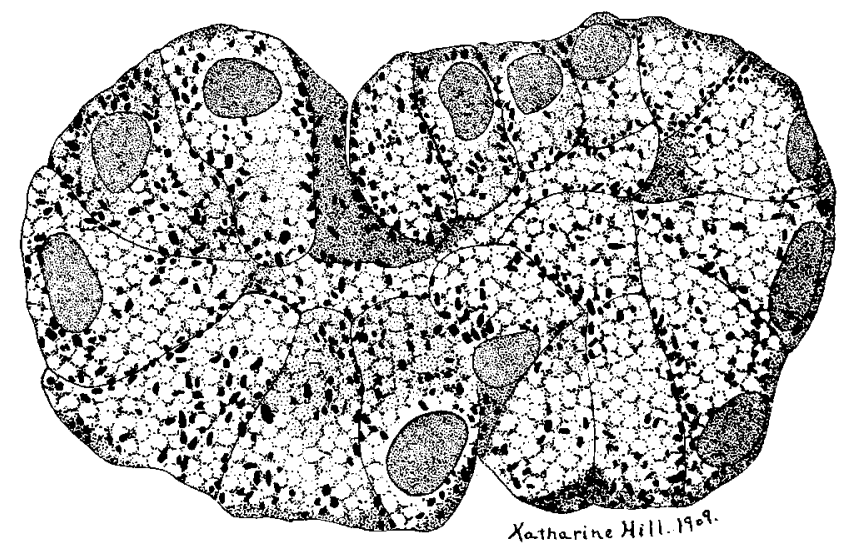

Fig. 14 Mitochondria in cells of tubule, Tech. IV, 2, e; V. 8. Zeiss, oc. 6, obj. $2 \mathrm{~mm}$. oil. Mitochondria are readily seen irregularly distributed throughout the cells.

have I seen in these large bulging cells mitochondria arranged in the form of filaments at the base of the cell. Nor is this to be anticipated, for these cells in other fixations (formalin Zenker and alcohol bichromate sublimate solution) are filled with granules from the base to the summit. Occasionally larger fuchsinophil granules are seen which resemble the secretion granules in size and shape, and are seen surrounded by the darker cytoplasmic network. These secretion granules when present show as much affinity for fuchsin as do the mitochondria. I have 
frequently observed these fuchsinophil secretion? granules in the orbital glands of frogs. Just what the significance of these granules is, I am unable to state. The explanation that they represent an intermediate stage between the secretion granules and mitochondria is unwarranted in view of the fact that so few are seen.

In some cells, though rarely, fuchsinophil globules are seen which are much larger than the secretion granules. It will be well to add here that red blood cells possess a marked affinity for fuchsin, although I was unable to make out mitochondria within them, confirming Cowdry ('14 c).

Other structures are seen in the cell. These are stained black with the osmic acid. The larger spherical ones undoubtedly are neutral fats. These can be demonstrated with Herxheimer's stain. The finer structures are liposomes. (See discussion under Fat.)

Dark cells: These cells are so termed because the darkly stained cytoplasm shows no network with empty meshes but instead is either filled with deep green stained secretion granules or is continuous. These cells correspond to types 2 and 3 heretofore described. In form they are irregularly cylindrical, pyramidal, elongated, or hourglass shaped due to indentation caused by the bulging type 1 cells. Many appear as demilunes. The position and form of the nucleus are similar here to that already described for these cells. The transitional cells of Noll are seen also wherein the central half of the cell possesses the characteristics of the light cells while the basal half shows the structures described in the dark cells. Throughout the cytoplasm mitochondria are readily observed. In the cells filled with secretion granules they are very plainly seen between the granules. The contrast is marked. In those cells which possess few or no granules, the red stained mitochondria are readily observed in the dark stained cytoplasm.

There is no regularity of distribution of mitochondria in the cells of the tubules in any of the types. Frequently one sees them in clumps at the central end, frequently at the basal end. 
More often, however, they are irregularly distributed throughout the cell. In all the cells of the tubules the mitochondria appear as very short irregular rods or as minute spheroids which may be slightly irregular in outline. In no instance have I seen long rods, threads, or loops as described especially for growing cells. Further, in the tubule the mitochondria do not form rows in the base of the cell and perpendicular to its base (filaments) such as found in the larger duct cells. Careful study failed to reveal any general irregularity in the quantity of these fuchsinophil granules. While some cells appear to possess more than do others yet the light cells (type 1) which represent the maximum of the granular stage apparently possess approximately the same number as do the dark cells (types 2 and 3 ) which represent either earlier or later stages of secretion granule formation. The mitochondria in these cells are not numerous when contrasted with those seen in the cells of the intralobular ducts (Cf. figs. 14 and 15). Consequently the granules do not appear to be used up in the formation of secretion granules.

Intercalary duct. The secretion granules in the intercalary duct are well preserved in Bensley's acetic osmic bichromate solution. In fact, so far as the preservation of secretion granules is concerned the effect of this solution is similar to Zenker's. The granules here have a marked affinity for the methyl-green. Between these green granules red stained mitochondria are readily observed. They simulate those in tubules so far as size, shape and distribution are concerned.

Larger ducts. In the intralobular and interlobular ducts the mitochondria are especially abundant. In the smaller intralobular ducts they may be so numerous that the entire cell, with the exception of the nucleus, appears to be composed entirely of these fuchsinophil granules. In these cells there exist marked irregularities so far as their distribution and arrangement are concerned. Some cells may be full of these granules while others again possess but relatively few. Generally the granules are arranged in rows - these rows being parallel to each other, perpendicular to the base of the cell, and extending through- 
out the entire length of the cell (fig. 15.) Cells are frequently seen, however, in which the mitochondria appear in heaps with no definite arrangement whatsoever.

The mitochondria of the ducts are readily seen when preserved in Bensley's sublimate alcohol bichromate solution (Technique IV, 2) and stained in copper chrome haematoxylin (Technique V, 5). Here they have an arrangement similar to that already described. Whether the mitochondria in the tubules and inter-

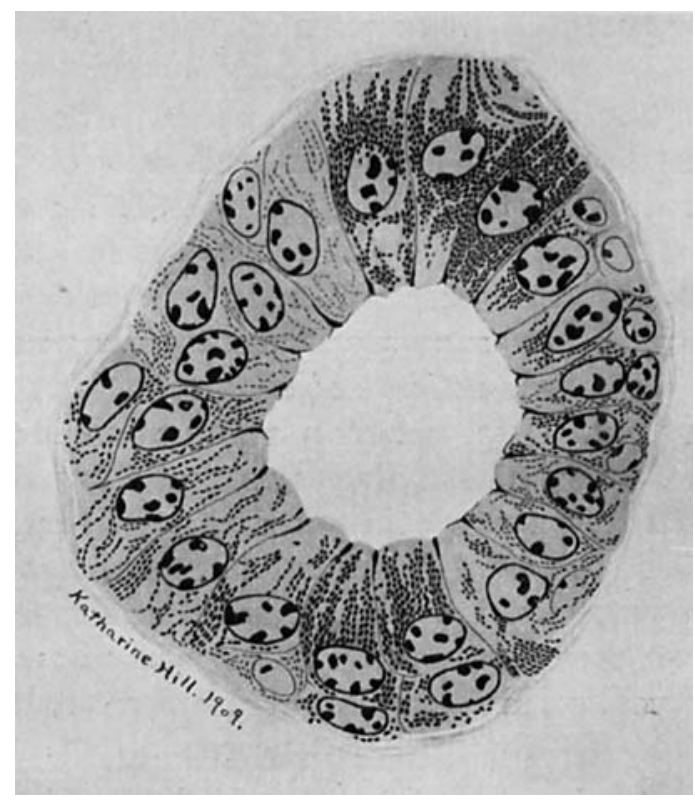

Fig. 15 Mitochondria in interlobular duct, Tech. sane as figure 14. Here they are arranged as filaments.

calary duct are preserved I can not say. It will be recalled that this fixative preserves the secretion granules and these stain deeply black in this copper stain. Consequently the mitochondria if present are masked. I did not see them in tissues of this fixation when stained with iron haematoxylin or the neutral stains-neutral gentian, and neutral safranin. In all likelihood 
mitochondria are affected by these latter stains but in the differentiation do not hold them so tenaciously as do the secretion granules. The presence of demonstrable mitochondria in tissues fixed in alcohol sublimate bichromate solution is interesting in view of the observations of others that mercuric chloride and alcohol fixatives do not preserve them.

The mitochondria were also stained by the intra vitam method of Michaelis ('00) (Technique VI, 1, 2). Here they appear as deep blue structures being the only stained constituents of the cell. In size, form and distribution they appear as already described.

Function of mitochondria in gland cells. Regarding the nature and function of mitochondria in general many hypotheses have been advanced which may be briefly summarized as follows: 1) the mitochondrial theory-that these elements are specific elements of the cytoplasm just as the chromosomes are fixed elements of the nucleus and like the latter arise from preformed elements in sex cells and are carried over in all mitosis-this view was championed by Benda and Meves. It has many supporters and is gaining ground. 2) Others do not accept the mitochondrial theory but claim that mitochondria arise from nuclear material, from ferment products of the centriole, or that they represent other phases in the metabolic activity of the cell. Many of those who accept the mitochondrial theory hold that these structures later develop into the fixed specific structures of cells; i.e., neurofibrils (Meves and Hoven '10), muscle fibrils, etc. Cowdry ('14 a) has demonstrated that in the case of nerve cells this is not true.

Cowdry (14 b) assumes that they have to do with the metabolism of the cell since they are almost coexistent with all active protoplasm. The fact that they do not occur in red blood cells (Cowdry), in superficial layers of epithelial cells (Firket), and in the terminal stages of the cycles of development of certain grains and legumes (Guillermond), according to Cowdry, partially substantiates this view because these cells are in the terminal stages of metamorphosis. Mitochondria, according to him, 
is in all liklihood a lipoid albumen complex. In nerve cells if they are numerous the lipoid granules are few and vice versa. In my opinion Cowdry's conclusions are correct.

Regarding their function in secretory cells, Altmann held the view that they were capable of forming secretion granules and also related to the formation and absorption of fat. Noll held views similar to Altmann regarding their relation to secretion. Schirmer could not say. Bensley ('11) states that certain types may possibly represent secretion antecedents. Champy ('11) makes the bold assertion that secretion granules originate from mitochondria. Hoven ('11, '12) also hold that the different products of the mammary gland originate from these granules and according to him this is true of the secretion granules for all glands. Arnold ('11) likewise holds the same view.

My studies on the lachrymal gland have not revealed any positive evidence that secretion granules have their origin from mitochondria. Certain facts may suggest that such a hypothesis is tenable. These are, 1) The absence of demonstrable antecedent substances suc as prozymogen-basophile substance (toluidin blue), prozymogen granules (intra vitam, neutral red), nuclear material in cytoplasm (Macallum reaction). 2) The secretion granules seem to make their appearance in any part of the cell independent of the nucleus. 3) The small amount of mitochondria in the secreting cells as contrasted with that in the cells of the ducts suggests that it may be used up in the formation of secretion granules.

On the other hand as valid objections can be advanced against this theory-1) Demonstrable antecedents for secretion granules are not found in many other serous and mucous cells. 2) The secretion may arise directly from other cytoplasmic structures independent of mitochondria. 3) If secretion granules originate from mitochondria one would expect to find variations in quantity depending upon the secretory stages of the cells. 4) The universal distribution of mitochondria in all cells speaks against a specificity in gland cells. Much light on this subject would result no doubt from both embryological and comparative study of glands aided by certain pharmacodynamic reactions. 


\section{BASAL STRIATIONS}

Whether such structures occur in the lachrymal gland as were early described by R. Heidenhain in fresh gland tissue and by J. Müller and Pflüger especially in the salivary ducts, has occasioned much discussion. Boll described 'Tränenröhren' in the lachrymal glands studied by him. Maziarski found none in man. Merkel found none in the lachrymal gland of the dog. Garnier, on the other hand, describes them in this gland in the dog and cat while Zimmermann claims that basal striations in the cells of the human lachrymal gland correspond to a lamellar structure. Fleischer, Hornickel, and Puglisi-Allegra have also recorded indications of the presence of such striatious or lamellar structure.

Thus we find much difference of opinion regarding the nature and presence of these structures. Even investigators working on the same gland have disagreed regarding them. In some contributions it is often difficult to determine just what particular cells are said to possess them. To Bensley ('11) we are especially indebted for clearing up the situation. 'He has shown that the so termed striations are due to two distinctly different substances -a) mitochondrial filaments of Altmann and Michaelis, and b) basal filaments of Solger and others. The former are seen in fresh tissue, are stained vitally by janus green, can be demonstrated by fixing tissues in acetic osmic bichromate solution and staining by Bensley's acid fuchsin methyl green method in which these filaments are fuchsinophilic in reaction, and are readily destroyed in solutions containing much acetic acid. The basal filaments, on the other hand, are due "to the fact that there are in the cell (speaking of his pancreatic acini fixed in chrome sublimate and stained in toluidin blue) unstained areas shaped like the filaments observed in the fresh cell after staining with janus green. These are the spaces originally occupied by the mitochondrial filaments." The basal filaments, then, are intermitochondrial basophile substance. In preparations fixed in solutions containing sufficient amounts of acetic acid to destroy the mitochondria this basophile substance is broken up into a feltwork of fine filaments. "These are the familiar basal fila- 
ments of Solger or the ergastoplasmic filaments of Prenant, Garnier, Bouin." Bensley is inclined to the opinion that these basophile filaments are fixation artifacts. At least he did not see them in the living cells.

Unfortunately many investigators have failed to take cognizance of this valuable contribution of Bensley's. Since its publication many still are laboring under the old confusion. Even Hoven ('12) speaks of "vegetativen Ergastidien und Chondriomen" as the same structures. Champy likewise fails to appreciate their difference- "Mitochondria und Ergastoplasma scheinen eine einzige und die gleiche Formation darzustellen."

Basal striations then are due to (a) Mitochondria which are either rod- or thread-like structures or granules so arranged as to form rows (Chondriomiten). The long axis of the former and the rows of the latter are generally arranged parallel to each other and perpendicular to the base of the cells. (b) An intermitochondrial cytoplasm which may be basophile in reaction and depends upon the existence of the former (a). When the mitochdonria are not preserved or remain unstained the latter (b) is prominent.

The presence, shape, and arrangement of mitochondria, then, should determine to a great extent whether basal striations are present. It will be recalled that in the discussion of mitochondria these structures in the cells of the secreting tubules and intercalary ducts are more or less spherical or very short rods and irregularly distributed throughout the cytoplasm. No parallel rods or rows were seen. Further, no deeply staining basophil substance was observed. Again the secretion granules filled the entire cell. These conditions exclude the possibility of basal striations being present. I have not observed any semblance of such in the tubules or intercalary ducts in any of my preparations fixed in at least ten different fixing solutions.

The intralobular and interlobular ducts on the other hand possess an arrangement of mitochondria necessary 20 form basal filaments. However, no intermitochondrial basophil substance is present. It was not until I had availed myself of Bensley's method that I was convinced that basal striations of any kind 
are present in these cells. In most fixations the basal half of the cell appears in no wise different from the proximal half. I could not account then for the claims of Fleischer who states that he saw 'pinselartige Aufaserung' in the cells of these ducts, ox-5 per cent ammonium chromate solution; Hornickel, beim Esel, and others. There is no doubt in my mind now but that the structures seen by these observers were imperfectly fixed mitochondria, which are readily seen in the acetic osmic bichromate-anilin fuchsin methyl green, and alcohol sublimate chromate-copper chrome haematoxylin preparations.

\section{HAT}

Axenfeld states that the presence of fat in the secreting elements of the human lachrymal gland is a normal condition and that apparently it is related to the secretory processes. Many globules of fat are found in the small dark cells. Kirschstein speaks of the large amount of fat in the interstitial connective tissue of the human lachrymal gland of old people. Ellenberger states that globules of fat are normal constituents of the lachrymal glands of all domestic animals except the pig, as does Lutz ('99). Stanculéanu and Théorhari describe much fat in the human lachrymal gland after epiphora. This condition probably was one of fatty degeneration. Schirmer-"Jedenfalls ist es von Wichtigkeit zu betonnen, dass in ganz normalen Drüsen grossere mengen Fett sich finden können." Hornickel- "Das Fett tritt als konstanter Zelleinschluss bei allen Tieren auf." According to him, in the horse and pig, the droplets of fat are small and in the periphery of the cell. In ruminants the distribution is regular, in the dog there is much variation, and in the cat the least amount.

More recent studies regarding the distribution of fat and lipoid substances in other tissues have been made by Bell ('10) and Kingsbury ('11). 'The former shows that in fresh tissues Herxheimer's stain affects all fat globules as well as the liposomes. According to him tissues fixed in formalin have a tendency to lose the liposomes while the neutral fat globules are unaffected. He shows that the granules obtained by Albrecht ('02) in the 
kidney after staining with neutral red are not lipoids. Kingsbury used osmic acid and Weigert myelin sheath method.

For my purposes I found that Herxheimer's stain (Technique III, 5) served best notwithstanding that it stains lecithin, cholesterin, and myelin. This however did not materially affect the results. Osmic acid was also used and proved satisfactory but with this fixation it is very difficult to differentiate between the finer lipoids and other structures within the cell. Numerous glands were examined and it was found that the fat content of the cells is subject to much variation. As was pointed out by Bell, fresh glands show more of the finer liposomes than do those after preservation for some time in formalin.

In some glands numerous droplets of fat were present in all the epithelial elements. The sizes of these varied from some as large as the nueleus to others so fine that they could barely be made out. In these glands the larger fat goblets were generally seen in the base of the cell while the finer ones were located more in the body and proximal portions. There was, however, much irregularity in the distribution. In other glands again the amount of fat present within the epithelial cells was limited to very fine globules irregularly distributed throughout the epithelial elements. An abundance of interstitial fat is always seen both in the capsule and the trabeculae.

In comparing these preparations with similar ones of other glands (pancreas and submaxillary gland of the same animals) the lachrymal gland in the majority of those examined showed very little more fat, if any, in the epithelial cells than did the others. My conclusions then are that frequently the lachrymal gland cells show considerable fat globules but that as a rule the cells in this gland do not possess more than are ordinarily seen in other secreting glands, and that where numerous globules are seen it should be considered in the nature of pathological degeneration.

Frequently the technique of preparing tissues by frozen method involves, by many, the infiltration with gum arabic. The latter stains red in Herxheimer's solution and unless it is completely removed it may simulate fat globules. I was misled by this at first. 


\section{SECRETION CAPILLARIES AND CEMENT SUBSTANCE}

Injection of various masses into the duct system of glands was an early method employed for the demonstration of secretion capillaries. Langerhans, Saviotti, Gianiozzi, Pflüger, Ewald, and Boll, among others, utilized this means. Objections, however, to this method were advanced by some observers in that the injection mass under pressure produced these capillaries. It was found that Golgi's silver impregnation method demonsstrated the secretion capillaries very clearly, as a black deposit is formed within them. Cajal, Retzius, E. Müller, Langendorf, Laserstein ('94), employed this means.

While intercellular secretion capillaries for serous glands in general are readily demonstrated by these methods as well as with certain stains much controversy has existed regarding their terminations. Some claim that they enter the cell, intracellular, as in the case of bile canaliculi, while others maintain that they remain intercellular throughout their course.

Noll described intercellular secretion capillaries in the lachrymal gland of the cat and Fleischer describes them in the tubules of the lachrymal gland of the ox, of varying lengths - some mere depressions, others almost touching the basal membrane, branching. Hornickel agrees with Fleischer regarding the presence and relations of these capillaries in the lachrymal glands of domestic animals. He further states that none are present in this gland in the pig and dog and explains this condition as being due to the fact that these glands are mucous in character as they react to mucous stains. Puglisi-Allegra demonstrated these structures by Golgi's method.

For the study of secretion capillaries I used the following: Kopsch-Golgi method (Technique II, 4); vital staining with pyronin (VI, 1); and tissues fixed in sublimate alcohol bichromate solution (IV, 2, a) or formalin bichromate sublimate solution (IV, 2, c) stained with iron haematoxylin, copper chrome haematoxylin, neutral gentian, and neutral safranin $(\mathrm{V}, 3,5,6,7)$. My results agree with those of Fleischer and Hornickel. 


\section{Kopsch-Golgi}

In Kopsch-Golgi preparations the lumina of the intercalary ducts and tubules and the secretion capillaries are definitely marked by the heavy black deposit, which gives an exact cast of them (fig. 16.)

In the tubules numerous secretory capillaries are seen radiating from the central irregular lumina. These vary in length, some forming only slight indentations between the cells while others almost touch the basement membrane. The ends of

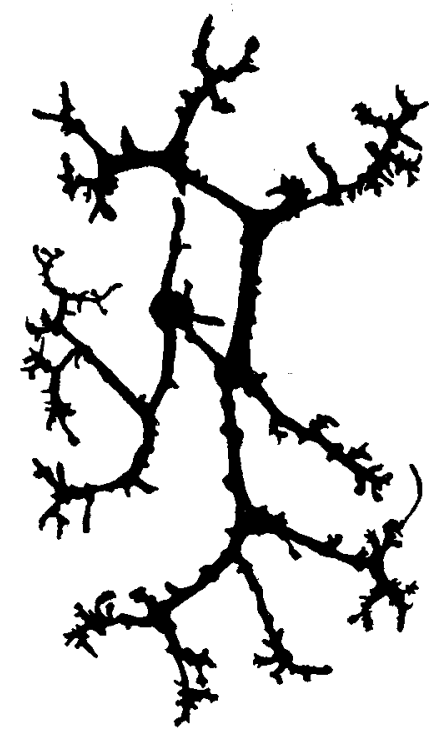

Fig. 16 Kopsch-Golgi silvęr impregnation, Tech. II, 4. Zeiss comp. 18, obj. $\mathrm{AA}$-showing secretion cupillaries. lumina of tubules and ducts.

these capillaries are rounded and in many instances terminate in slight bulb-like swellings or knobs. Many branch at irregular distances from their origin. Some branch immediately upon leaving the lumina-others, after coursing some distance between two cells, branch to straddle the small demilune cells. In many instances the terminal branches are so numerous that they form irregular rosettes with many short club-like rays projecting in every direction. These rays frequently appear to be 
intracellular although it is impossible to demonstrate by this method that such is the case.

The lumina of the intercalary ducts appear either smooth and even or many short knot-like projections are seen on either side showing that the surface cells which form the lumina are either in close apposition to each other or have indentations between them. That both conditions may be present has been considered in "Duct System and Tubules."

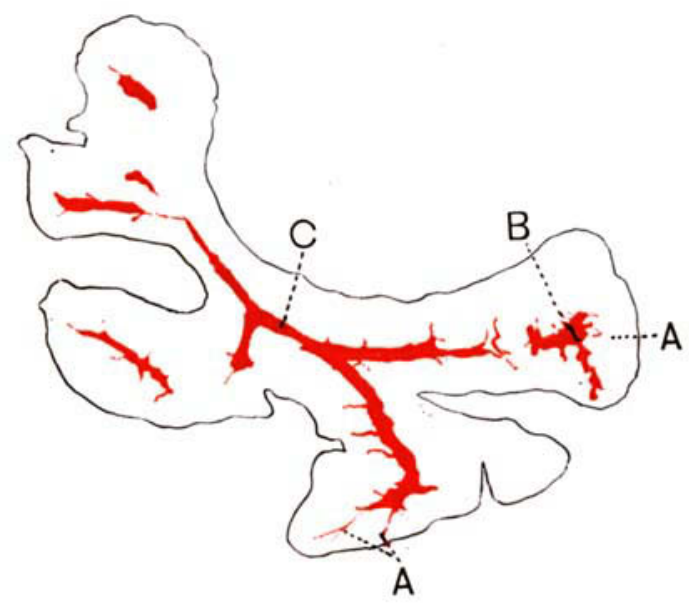

17

Fig. 17 Tubule and intercalary duct after vital staining with pyronin, Tech. VI, 1. A, secretion capillaries; $B$, lumen of tubule; $C$, lumen of intercalary duct.

\section{Pyronin}

The most satisfactory method for the study of secretion capillaries is the vital staining with pyronin. The capillaries as well as the lumina of the tubules and ducts stain a deep red while the cells are unstained (fig. 17). The advantage of this method lies in the fact that very thin sections from 2 to $5_{\mu}$ can be obtained and these can be further stained with either iron haematoxylin or copper chrome haematoxylin. Thereby the relation of the capillaries to the other structures of the cells can be readily made out. 
In sections thus prepared the red stained secretion capillaries are seen between the cells. Frequently they become finer and finer and gradually disappear as they approach the basal ends

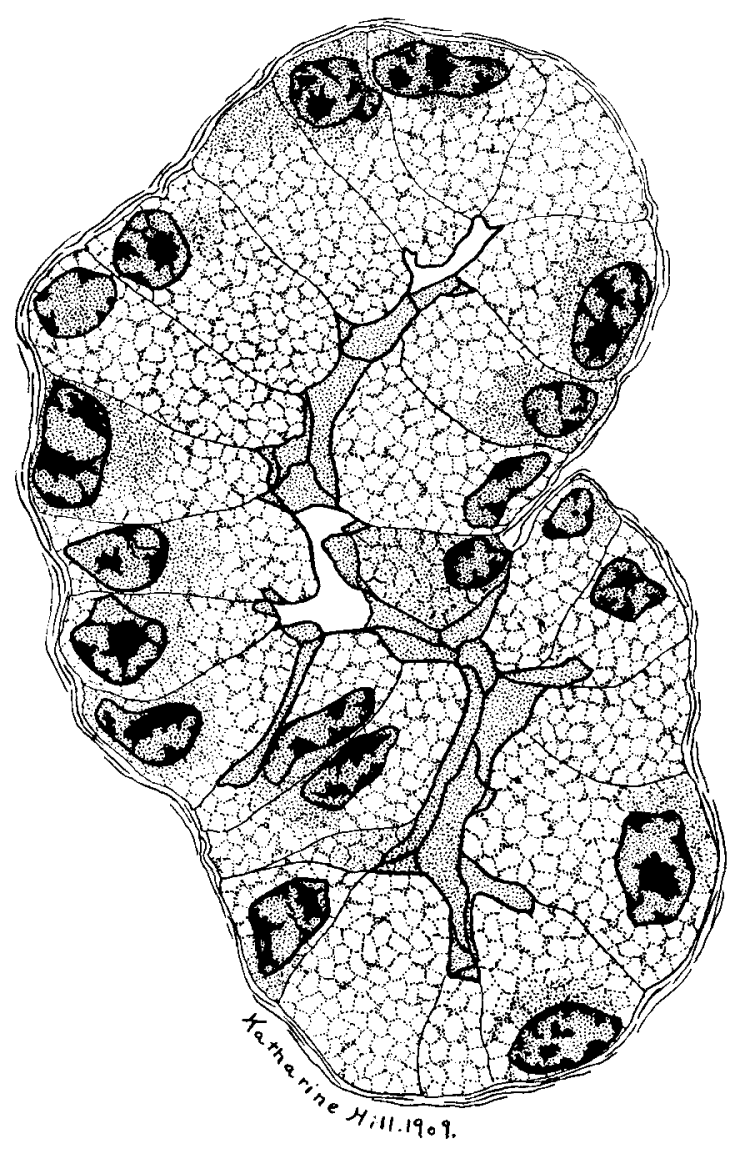

Fig. IS Tubule showing seeretion eapillaries and cement lines. Secretion gramules are not preserved. The intergranular cytoplasmie network is seen.

of the cells. Others terminate in bulb-like swellings. In no instance was I convinced that they had an intracellular termination. 


\section{Fixed and stained preparations}

Secretion capillaries are readily seen in tissues stained with the serous granule stains already named (figs. 18 and 19). Here they are seen as intercellular structures and are outlined by a thin deeply stained cement substance. These sections plainly show that the secretion capillaries are much modified by the stages of granule formation within the cells. If bordering cells are in a maximum stage the capillaries are not seen, only the cement line projects downward between these cells. On the other hand, if the cells are in a medium or minimum granular stage the capillaries are wide and open and outlined by the cement substance.

In none of my preparations have I observed true intracellular secretion capillaries, notwithstanding they have been described by others. It might be well to add here that the literature on this particular subject is very confusing. Under the caption of intracellular canaliculi, one finds at least three separate and distinct types of these canals described without any particular discrimination as to their nature--(a) intracellular secretion canaliculi as described by E. Müller and R. Krause; (b) intracellular blood capillaries, in liver cells, as shown by Schäfer; and (c) the canalicular apparatus (reticular apparatus) (Holmgren's canals) which is found in most animal and vegetable cells. The adoption of a uniform nomenclature is certainly desirable in this instance. It is interesting to observe that similar methods (silver impregnation) have been used for the demonstration of all of these and is it not possible that in many instances intracellular secretion capillaries have been described when the canalicular apparatus of Holmgren alone was present? The latter is discussed under $\mathrm{X}$.

The cement substance of glands was first described by Heidenhain and later by Zimmermann, Bonnet, Cohn, Solger, Carlier, Meyer, Oppel, Bensley, and others. Kolossow, on the other hand, doubted its existence.

I have already described the cement structures in the larger ducts (VI. The Duct System and Tubules.) Cement lines are 
readily demonstrated with iron haematoxylin, copper chrome haematoxylin, neutral gentian, and neutral safranin. In the tubules and intercalary ducts they appear either outlining the lumina and the secretion capillaries or as lines varying in length projecting basalwards between the cells (fig. 19). As already

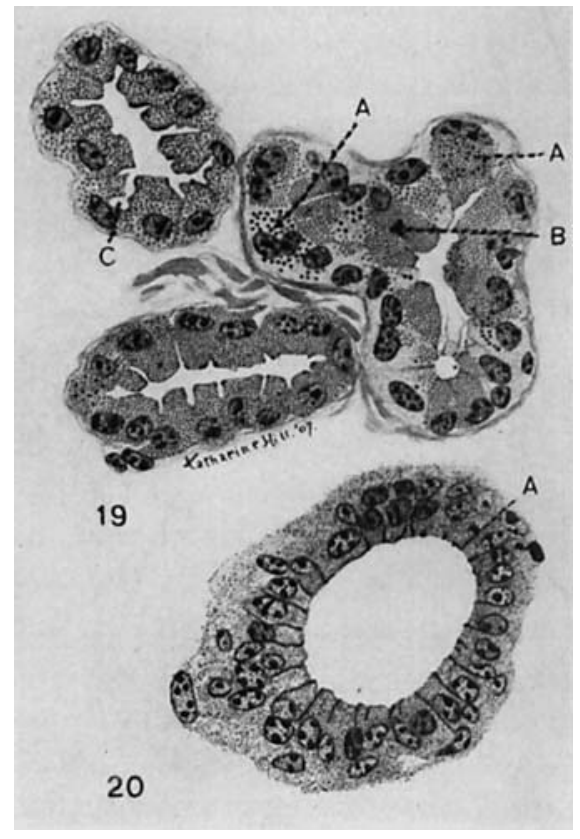

Fig. 19 Tubules, Tech. IV, 2, a; V, 6. Zeiss, oc. 2, Leitz. obj. iz oil-showing secretion capillaries and cement substance. Note varying intensities of staining of the granules. $A$, deeply stained granules; $B$, faintly stained granules; $C$, secretion capillaries.

Fig. 20 Intralobular duct, cross section, tech. same as figure 19 . Cement lines projecting towards the base of the cells and between them- $A$.

stated, the cement substance is much modified in appearance by the secretory stage of the cells. If the cells are in a maximum stage of granule formation the secretion capillaries may be completely obliterated, in which case the cement substance likewise may be completely obscured or may be seen as fine lines extending between the cells towards their basal membrane. 
As Carlier ('99) and Bensley ('02) have shown in gastric epithelium, the cement substance frequently appears on the free surface of the cell as a fine irregular network.

\section{CANALICULAR APPARATUS}

It has been shown that many types of cells possess within their cytoplasm very fine anastomosing canaliculi. These were first described by Golgi ('98) in the nerve cells. Later his students, Negri ('00) among others, demonstrated them in many gland cells. Golgi's silver impregnation method was used for the demonstration of these minute canals.

Kopsch ('02) showed that they could be demonstrated by long immersion of the tissue in 2 per cent osmic acid. By this method von Bergen ('04) demonstrated the canaliculi in a great many animal cells.

Holmgren ('02), in a number of papers beginning with 1899, has contributed much to this particular subject, using picric acid-sublimate, toluidin blue and erythrosin method, and later trichloracetic acid and fresh Weigert's resorcin fuchsin. At first Holmgren thought that the canals were lymphatic in nature as he had demonstrated to his own satisfaction that they communicated with the exterior. Later, mainly as a result of his second technique, he held that these canals (in nerve cells) possessed a network of fibres which had their origin from the nerve capsule. To this network of anastomosing fibres he applied the term spongioplasma and from this developed the well known 'Trophospongium theory.'

Bensley ('10 b) has shown the analogy of these canaliculi to the vacuoles of plant cells. In the latter (root tip of onion) using formalin bichromate sublimate solution and Kopsch solution as fixatives, he has demonstrated that in the youngest cells the well known vacuoles appear as a canalicular system similar to that in the characteristic animal cell. As the plant cell becomes older the canals enlarge and finally form vacuoles. These were seen by him in the living plant cells, as well. In no instance did he find these canals communicating with the exterior. Bensley ('11) describes the canaliculi in both the acinus 
cells and islet cells of the pancreas. In the former, after stimulation in order to rid the cell of the secretion granules which hide the canaliculi, they are seen- "the apparatus is located in the portion of the cell between the nucleus and the lumen but branches of the canal may appear basalwards along the sides of the nucleus." In the islet cells they resemble those in the acinus both in topography and relation. In neither were communications with the exterior seen.

Cowdry ('12 b) describes them in the spinal ganglion cells of the pigeon.

That these canaliculi communicate with the exterior of the cell has been claimed by Holmgren and Retzius, among others; that they do not, by Golgi, Kopsch, Misch, Studnicka, and Bensley.

The canalicular apparatus in the cells of the tubules of the lachrymal gland of the ox can not be easily studied owing to the general presence of secretion granules. However, in many glands cells with few or no granules were seen in which this apparatus could be made out readily. It was seen for the most part in that part of the cytoplasm proximal to the nucleus. It appears as a network of open spaces or canals with branches which frequently terminate in slight nodular enlargements. I layer of cytoplasm was always seen between these terminations and the cell membrane. The apparatus at one end comes into close proximity to the nucleus, and processes are frequently seen extending around the nucleus towards the base of the cell.

This apparatus is seen best in sections preserved in formalin Zenker's solution, where it is seen as clear spaces in the cytoplasm. In the tissue stained by the vital pyronin method, which demonstrates the intercellular secretion capillaries, the canalicular apparatus of Homlgren can be made out as well. Here also it appears unstained, in contrast to the red secretion capillaries, and is seen as clear spaces in the cell. Consequently it is readily differentiated from the intercellular structures. Since the pyronin stains the secretion substance, one can readily conclude that the apparatus is in no manner concerned with the secretion substance of the cell and is independent of the secretion capillaries. 
XI. TECHNIQUE

I. For the study of the gross characteristics of the gland, calves' heads were embalmed by injecting, under pressure, into the carotid arteries equal parts of glycerine, 95 per cent alcohol, and carbolic acid full strength. A suspension of red lead, starch and hot water was then injected, shortly after which dissection of the orbit was begun.

II. For the study of the ducts and their ramifications the following methods were used:

1. Flint ('02), Spalteholz ('97).

2. Injection method, see Hüber's technique given in American Journal of Anatomy, vol. 6, 1907, The Arteriolae Rectae of the Mammalian Kidney. The celluloid mass withstood the corrosion much better than the celloidin. Total peptic digestion required on the average two weeks.

3. Vital staining method with pyronin (See VI, 1).

4. Kopsch ('10)-Golgi chrome silver method (somewhat modified) for the demonstration of lumina of tubules and secretion capillaries.

III. For the study of the connective tissue framework.

1. Flint, Spalteholz-After complete digestion, tissues were imbedded in paraffin and thin sections made.

2. Mall's method ('96) for the demonstration of reticulum with frozen sections $(25 \mu)$.

3. Tissues fixed in 70 per cent alcohol, imbedded in celloidin, sections 10 to $20 \mu$ thick, fastened on slides, and digested and stained by Mall's method were especially useful for the study of the framework. The method (Jeffrey's) was as follows: Sections were placed in a mixture of equal parts of glycerine and 95 per cent alcohol for some time before mounting. A thin coating of Mayer's albumin was applied to clean slide, to which section was transferred. A piece of smooth writing paper was placed on the section and over this several layers of blotting paper. A second slide was prepared in the same manner and the two were bound tightly together with the blotting paper in the middle. This was placed in a thermostat $60^{\circ} \mathrm{C}$. for one-half hour after which the slides freed from the paper. The slides 
(to which the sections adhered) were then placed in alcohol and ether until the celloidin was dissolved (15 to 20 minutes); transferred to absolute alcohol, 95 per cent alcohol, 70 per cent alcohol, and finally to water; and digested in pancreatin, which required from one to three days.

Tissues fixed in any of the chrome salts were not affected by pancreatin in one week's time.

4. For further study of the connective tissue, tissues were fixed in Zenker's solution, embedded in celloidin and stained as follows: (a) for collagenic fibres and smooth muscle-Van Gieson's, Mallory's and haematoxylin and eosin; (b) for elastic fibres-Weigert's and Unna-Taenzer ('10).

5 . For the study of fat in connective tissue, pieces of gland were fixed in 10 per cent formalin twenty-four hours, washed, cut by frozen method, and stained by Herxheimer's ('10) method -absolute alcohol 70 cc., sodium hydroxide (10 per cent solution) 20 cc., water $10 \mathrm{cc}$., Sharlach R. to saturation. After staining for from five to ten minutes sections were washed in 70 per cent alcohol, washed in water, and mounted in glycerin.

IV. For the study of secretion granules and the finer histological characteristics of the cell.

1. Granules in the intercalary ducts-Fixed in Zenker's, embedded in celloidin, fastened to slides (see III, 3); celloidin dissolved off ; and section stained in muchaematein or mucicarmin prepared according to Bensley's method (see Stains).

2. Granules in the tubules as well as those in the intercalary ducts and the minute cell structures-Small pieces of tissues were fixed in the following solutions, embedded in paraffin, and cut from 2 to $5 \mu$ thick.

(a) Bensley's ('96) sublimate alcohol bichromate solutionequal parts of saturated solution $\mathrm{HgCl}_{2}$ in 95 per cent alcohol and $2 \frac{1}{2}$ per cent aqueous solution of $\mathrm{K}_{2} \mathrm{Cr}_{2} \mathrm{O}_{7}$. Small pieces of the tissue were placed in this fixative for about three hours. The solutions were not mixed until time of using. Fresh mixtures were used every thirty minutes during fixation.

(b) Modification of Kopsch's formalin bichromate solution- 
Formalin 40 per cent, 1 part..

$\mathrm{K}_{2} \mathrm{Cr}_{3} \mathrm{O}_{7} 3$ per cent Aq. sol., 3 parts one part

Sat. sol. of $\mathrm{HgCl}_{2}$ in 95 per cent alcohol one part

Distilled water................................ two parts

Fixative was made at time of using. Small pieces of tissue were placed in it for about three hours to insure proper fixation.

(c) Formalin bichromate sublimate method-Fixed for twentyfour hours in the following solution: neutral formalin $10 \mathrm{ec}$. and Zenker's solution without the acetic acid $90 \mathrm{cc}$.

(d) 70 per cent alcohol.

Tissues fixed in (a), (b), (c), and (d) were stained in muchaematein, mucicarmin, iron haematoxylin counterstained with mucicarmin, Bensley's ('11) neutral gentian, Bensley's ('11) safranin-acid violet, and copper chrome haematoxylin used singly or with mucicarmin (see Stains).

(e) Acetic osmic bichromate method (Bensley '11, p. 308).

V. Staining methods.

1. Muchaematein (Bensley '03)--haematein 1 gram, aluminum chloride 0.5 gram, 70 per cent alcohol $100 \mathrm{cc}$. Haematein and chloride rubbed together, dissolved in alcohol and allowed to stand for a week to insure ripeness. (If alcohol is made by diluting absolute alcohol with tap water stain can be used immediately.) Sections were flooded with stain, placed on stage under microscope and watched until deep color, then rapidly washed in 95 per cent alcohol, dehydrated, cleared and mounted in xylol balsam. The granules in the intercalary duct stained definitely and intensely blue.

2. Mucicarmin-1 gram of carmin and 0.5 gram aluminum chloride ground in porcelain evaporating dish after which small amount of water was added; heated over a Bunsen burner, grinding process continued during heating, till mass became very dark red (almost black) then dissolved in absolute alcohol and filtered. Stain must be used while fresh. Technique same as $\mathrm{V}, 1$.

3. Iron haematoxylin.

4. Iron haematoxylin counterstained with mucicarmin.

5. Copper chrome haematoxylin (Bensley '11, p. 310). 
6. Neutral gentian - solution of gentian-violet (crystal violet) precipitated by its equivalent of orange- $\mathrm{G}$ solution (Bensley '11, p. 308).

7. Safranin-acid violet - precipitate of a saturated solution of safranin $O$ with solution of acid violet (Bensley's 11, p. 309).

8. Acid fuchsin methyl green-(a) Altmann's acid fuchsin anilin solution: acid fuchsin 20 grams, anilin water $100 \mathrm{ce}$. and (b) 1 per cent solution methyl green (Bensley '11, p. 309).

9. Macallum's ('95) iron reaction.

VI. Vital staining methods.

1. Pyronin. (Bensley '11, p. 305.) About eight liters of 1-1000 solution in isotonic salt solution injected into the carotid arteries of heads of freshly killed calves; cut arteries in neck clamped off to prevent leakage. Lachrymal gland was deeply stained. By means of the Valentine knife sections 0.5 to $1 \mathrm{~mm}$. were cut and studied with binocular. The acini or tubules stained only lightly while the ducts, as well as the lumina of the acini including the intercellular secretion capillaries, were deeply stained. The capillaries were best studied by fixing small pieces of this pyronin stained gland in 8 per cent solution of ice cold ammonium molybdate for twelve to twenty-four hours, after which they were placed in ice cold 95 per cent alcohol one hour, absolute alcohol one hour, toluol one hour, and paraffin one-half hour. Sections were made and capillaries studied with the microscope.

2. Janus green - one gram in 15,000 cc. of isotonic salt solution. (Bensley '11, p. 305.) Technique same as VI, 1.

3. Methylene blue-one gram in $10,000 \mathrm{cc}$ of isotonic salt solution. Technique same as VI, 1.

4. Neutral red - one gram in $15,000 \mathrm{ec}$. of isotonic salt solution. Technique same as VI, 1 . This stain cannot be fixed.

For detailed consideration of these stains see Bensley (11).

XII. MISCELLANEOUS-OTHER FIXATIONS AND STAINS

In addition to the technique outlined and referred to in the general discussion other methods of fixation and staining were employed, the results of which may be briefly summarized as follows: 
1) Fixations with alcohol failed to preserve the secretory granules and the mitochondria. The cells of the tubules show only the intergranular cytoplasm which appears as a network.

2) When 5 per cent glacial acetic acid was added to the 70 per cent alcohol it was found that the granules were partially preserved. In these preparations many of the ring and crescent granules of Fleischer were seen.

3) The same results outlined in (1) are obtained when Carnoy's fixation is used.

4) The secretion granules are fairly well preserved in picric acid. When stained in the neutral stains of Bensley, one is impressed with the varying intensities to which granules stain. One cell may be filled with the characteristic dark blue granules while the neighboring cell may be full of lightly stained ycllowish granules. The granules in cell type 1 generally show in this fixation greater affinity for the neutral stains than do those in other cells.

5) Tissues fixed in trichloracetic acid preserved the secretion granules fairly well. However, they did not show great affinity for the neutral stains, for after slight differentiation they are but faintly stained.

It will be recalled that fixations (4) and (5) were used by Fleischer in the demonstration of ring and crescent granules. While these were frequently seen in these fixations they were by no means constant.

6) Using Kolossow's method, I was unable to demonstrate the epithelial intercellular bridges as described by him. Much shrinkage of tissue was in evidence.

My experiments with neutral red, vital staining, were not very satisfactory. Four different calves heads were stained by this method and in each instance the gland remained either uncolored or appeared slightly pink. This was found to be in marked contrast to the results obtained in other animals where the gland stained deeply red (monkey). Microscopic examinations show that all cells are diffusely but faintly stained. The granules of the tubules and intercalary ducts also appear very faintly stained. As elsewhere stated, careful examination 
failed to reveal prozymogen granules as described by Bensley for the pancreas.

Vital staining with methylin blue showed the sympathetic nerve fibres of the gland, as demonstrated by Dogiel. The granules are not stained.

\section{SUMMARY}

1. The lachrymal gland in Bovidae is made up of two partsa Pars superior which comprises by far the greater bulk of the gland and an auricular appendage which extends downwards between the Bulbus oculi and the outer bony orbital wall-the Pars inferior.

2. The gland is composed of a series of from six to eight compound tubular glands serially arranged and in close apposition to each other. Each gland may be subdivided, beginning with the terminal opening and proceeding to the secretory elements, into the following structures: main duct, primary duct, interlobular duct, intralobular duct, intercalary duct, tubule or alveolus.

3. Elastic fibres are abundant in the capsule and in the larger interlobular septa. They appear to some extent in the more prominent intralobular septa but in the finer they are not seen. These fibres do not surround the individual secreting tubules as claimed by Boll, Schirmer, Fumagalli, and others, in various animals. Lymph cell infiltrations of the septa are not normal conditions though so held by Schirmer for this gland in man and by Fleischer in the ox. The basement membrane is formed by a reticular connective tissue similar to that seen in the salivary gland. In addition to this membrane, irregular, anastomosing connective tissue cells are seen between and surrounding the tubules together with plasma cells, endothelial cells, and lymph cells. While smooth muscle cells are frequently seen occurring singly in the capsule and in the largest interlobular septa, they are not found within the lobule surrounding the individual tubules as held by Kollosow, Zimmermann and others.

4. The epithelial cells of the main duct are irregular in outline and arranged in several layers. Numerous goblet cells are seen. 
In the primary ducts a gradual reduction of both goblet cells and the layers of epithelial cells takes place. The interlobular ducts possess no goblet cells, and two layers of epithelial cells form the lumina. In the intralobular ducts one or two layers of epithelial cells are seen. The outer layer gradually disappears in the smaller intralobular ducts and in the intercalary ducts.

5. Secretion granules are present in both the intercalary duct and in the tubules. They are not found in the other ducts. The granules are readily seen in all fresh glands when examined in serum or isotonic salt solution. They disappear when the fresh cells are placed in distilled water but reappear upon the addition of 2 per cent sodium chloride solution.

6. The granules in the intercalary ducts are preserved when the tissue is fixed in Zenker's solution and stain specifically in muchaematein and mucicarmin. They are not stained-when fixed in Zenker's - with the serous granule stains. The granules in the tubules are not preserved as a rule in Zenker's solution. This phenomenon suggests that the cells or the tubules may differ in function from those of the intercalary duct. I am not prepared, however, to make this claim.

7. The granules of both the intercalary duct and the tubules are fixed in Bensley's alcohol sublimate bichromate solution and in formalin bichromate sublimate solution. When tissues are fixed in these solutions the granules in both the tubules and intercalary ducts stain in the well known mucous stain-muchaematein and mucicarmin as well as in the serious granule stains iron haematoxylin, copper chrome haematoxylin, neutral gentian, neutral safranin. After staining tissues fixed in the former solution with iron haematoxylin and then counterstaining with mucicarmin, all the granules in certain cells stain black with the former stain and all the granules in other cells stain red in the latter, while in other cells both black and red granules are seenthus showing that even within the same cell some of the secretion granules are affected by serous stains while others are affected by mucous stains. Notwithstanding this double staining reaction, there is not sufficient evidence to claim that the cells forming the tubules are heterogeneous in character. 
8. The cells constituting the tubules or acini present different pictures depending upon the secretory stage they are in. In the maximum granular stage the cells are large spherical or oval (bulging), the granules fill the entire cell and the nucleus is flattened against the base. When the secreting cavity is made up of these cells it may have the form of an alveolus or acinus. Cells in a medium or minimum granular stage are cylindrical, pyramidal, hour-glass shaped, or may appear as crescents. As a rule they are seen compressed between the large bulging cells in each tubule: They are frequently seen, however, making up the entire secreting cavity. These cells are much reduced in size when compared with the former. Granules may fill the entire cell or only few may be present. Occasionally these cells show no granules. The nueleus is round or oval and is always separated from the base of the cell by a zone of cytoplasm.

9. The cells of the intercalary duct do not show such disturbances. Whether these cells are in a maximum or minimum granular stage, the size and shape remain practically the same. No changes are seen in the form or position of the nucleus.

10. The lachrymal gland of the ox is not a mucous secreting gland notwithstanding that the granules stain specifically in the mucous stains. I do not agree with other observers, namely Fleischer, that the secretion granules in the process of formation regularly assume various peculiar forms such as rings and demilunes. Rings and demilunes are sometimes seen in fixed preparations but these peculiar forms are no doubt due to the action of the fixation fluid.

11. No light has been gained as a result of my studies on the origin of secretion granules. The absence or at least the presence of very small amounts of demonstrable secretion granule antecedent substances-prozymogen, nuclear derivatives, etc.does not admit of the hypothesis that the nucleus is the sole originator of secretion granules. On the other hand the abundance of granules, their variation in size without regard to position in the cell (the largest and smallest granules are seen side by side in any portion of the cell), their apparent origin from the cytoplasm- all strongly suggest that the cytoplasm plays a 
very important rôle in the formation of granules. I have seen no evidence that mitochondria are diretly concerned in the production of secretion granules.

12. Mitochondria are abundantly present in the cells of the larger ducts-intralobular, interlobular, etc.-where they are either arranged as filaments or appear irregularly distributed without any special arrangement whatsoever. In the cells of the intercalary duct and secreting tubules they are much less numerous and are distributed irregularly throughout the cytoplasm. The number of mitochondria for these cells appear approximately equal-whether the cells are a maximum granular stage or contain the minimum of granules.

13. I did not find that an abundance of fat globules in the secreting cells is characteristic of the lachrymal gland as claimed by other investigators. While glands were studied in which numerous fat globules were observed, in the vast majority the quantity of fat globules was found to be no more than that observed in the submaxillary gland and the pancreas.

14. Intercellular secretion capillaries varying in width and length - depending upon the secretion stages of the cells - and bounded by cement substance are prominently seen in the tubules. In the intercalary duct these capillaries may not be seen or they may appear as slight indentations between the cells. Cement substance is found throughout the secretion passages. Pyronin when used intra vitam selectively stains the secretion capillaries.

15. The canalicular apparatus is readily seen in the cells of the lachrymal glands. In the cells of the tubules they are only seen when few or no granules are present.

16. I have failed to observe the constant presence of centrosomes described by Zimmermann and Fleischer. Likewise I have failed to find the constant presence of the paranucleus described by other investigators.

I am especially indebted to Professor R. R. Bensley of the University of Chicago for numerous suggestions. This work was begun in his laboratory under his inspiring direction. Since 
then I have taken advantage of his numerous contributions to the knowledge of gland structures, and the new methods of technique devised by him have been of greatest value in my work.

\section{BIBLIOGRAPHY}

Albracht, E. 1902 Neue Beiträge zur Pathologie der Zelle. Deutehe Path. Gesell.

Alt, Adolph 1900 Trans. Acad. Sc., St. Louis, vol. 10, pp. 185-207. Quoted from Schwalbe's Jahresh.

Altanan 1890 Die Elementarorganismen und ihre Beziehungen zu den Zellen. Leipsig.

Arnold, G. 1911 The rôle of chondriosomes in the cells of the guinea pig's pancreas. Arch. f. Zellforsch., Bd. 8, pp. 252-271. Quoted from Schmidt's Jahresb., 47 Jahrgang, B. f. d. 1912, Berlin, 1913, p. 67.

AxenfFin, TH. 1900 Ueber die feinere Histologie der Tränendrise. besonders über das Vorkommen von Fett in den Epithelien. Bericht über die 28 Vers der Ophth. Gesell, Heidelburg, S. 160. Quoted from Fllenberger.

See also--Bemerkungen zur Physiologic und Histologie der Tränendrüse. Bericht d. Ophth. Gesell. zu Heidelberg.

Bert, E. T. 1910 The staining of fat in epithelium and muscle fibres. Anat. Rec., vol. 4, no. 5, p. 199.

Bensiwx, R. R. 1896 The histology and physiology of the gastric glands. Proceed. of the Canadian Institute, p. 11.

1902 The cardiac glands of mammals. Am. Jour. Anat., vol. 2, No. 1, pp. 105-156.

1903 The structure of the glands of Brunner. The Dec. Pub. University of Chicago, vol. 10, pp. 1-50.

1908 Observations on the salivary glands of mammals. Anat. Rex, vol. 2, pp. 105-107.

1910 a On the so-called Altmann granules in normal and pathological tissues. Trans. Chicago Path. Soc.

$1910 \mathrm{~b}$ On the nature of the canalicular apparatus of animal cells. Biol. Bull., vol. 19, 3, p. 179 .

1911 Studies on the pancress of the guinea pig. Am. Jour. Anat., vol. 12, no. 3, p. 298.

von Bergen, F. 1904 Zur Kenntniss gewisser Strukturbilder Netz-apparate, Saftkanälchen, Trophospongien) im Potoplasma verschiedener Zellenarten. Arch. f. Mik., Anat. Bonn, vol. 64, p. 498.

Bernard 1856 Mémoire sur le pancréas et le rôle du sac pancréatique. Paris.

Biedermann 1886 Zur Histologie und Physiologie der Schleimsecretion. Wiener Sitzungs Berichte, 3, Abth.

Böhm and Davidofr 1903 Lehrbuch der Histologie des Mensehen. 1900 ibid, Huber's edition, p. 432.

Boll, Franz 1868 Ueber den Bau der Tränendrüse. Arch. f. Mik. Anat., Bd. 4, pp. $146-153$. 
Boll, Franz 1871 Die Tränendrüse. Stricker's Handbuch der Lehre von den Geweben, Leipsig, 2, p. 1161.

Cajal, Ramon Y 1896 Estudios histologicos sobre los tumores epiteliales. Rev. trim. micr., T. 1, (Schäfer).

CARLIer, E. W. 1899 Changes that occur in some cells of the Newt's stomach during digestion. La Cellule, Louvain, T. 16, pp. 250-255.

Champy, C. 1911 Recherches sur l'absorption intestinale et le rôle des mitochondries dans l'absorption et la sécrétion. Arch. d'Anat. Micr., T. 12, F. 1, pp. 55-170. Quoted from Schmidt's Jahresb. 46, Jahr 1911-12.

CowDry, E. V. 1914 a The development of the cytoplasmic constituents of the nerve cells of the chick. I. Mitochondria and neurofibrils. Am. Journ. Anat., vol. 15, no. 4.

$1914 \mathrm{~b}$ The comparative distribution of mitochondria in spinal ganglion cells of vertebrates. Am. Jour. Anat., vol. 17, no. 1 .

DantchakofF 1905 Les cellules plasmatiques dans la glande sousmaxillaire du lapin. C. R. de l'assve des Anat. 7, Reun Genève.

Dogiel, A. S. 1893 Die Nervenendigen in der Thränendrüse der Säugetiere. Arch. f. mik. Anat., Bd. 42, S. 632-647.

Drasch 1889 Beobachtungen an lebenden Drüsen mit und ohne Reizung der Nerven derselben. Arb. aus d. Physiol. Inst. in Leipsig.

Dubreurl 1907 Les glandes lacrymales des mammiferes et de l'homme. A. Rey et Cie, Lyons.

v. EbNer 1873 Die acinösen Drüsen der ZZunge und ihre Beziehungen zu den Geschmacksorganen. Graz.

1902 Kölliker's Handbuch der Gewebelehre des Menschen, Bd. 3, 6 Auflage, Leipsig, p. 881.

Ellenberger, W. 1906 Handbuch der Vergleichende mikroskopischen Anatomie der Haustiere, Erste Bd., p. 542; p. 545.

Elumberger, W. And Batm, H. 1908 Anatomie der Haustiere, Zwölfte Auflage, p. 935 .

Ellenberger, W. and Gưnther 1888 Grundriss der Vergleichende Histologie der Haussäugetiere, pp. 187-88.

Falchr, F, 1905 Sur le developpement de la glande lacrymale. Arch. ital. Biol., vol. 44, pp. 412-415.

Fischer, A. 1899 Fixierung, Farbung und Bau des Protoplasmas. Jena.

Fueischer, B. 1904 Beitrage zur Histologie der Tränendrüse und zur Lehre von den Secretgranule. Anat. Hefte., Bd. 26, pp. 103-166.

Flemming, W. 1888 Ueber den Bau und Einteilung der Drüsen. Arch. f. Anat. u. Physiol., Anat. Abt. pp. 287-302.

Flint, J. M. 1902 A new method for demonstration of the framework of glands. Johns Hopkins Bulletin, vol. 13, p. 48.

Franck, L. 1883 Anatomie der Haustiere.

Frerichs 1846 Tränensecretion. R. Wagner's Handwörterbuch, 3, pp. 617631 .

Frey, H. 1859 Histologie und Histochemie des Menschen. Leipsig.

Fumagalli, Arnaldt 1897 Il tessuto elastico nella glandola lacrymale dell? uoma. Monit. Zool. Ital., Anno 8, pp. 167-69. 
Garnier, Ch. 1900 De la Structure et du Fonctionnement des Cellules glandulares Sereuses. Jour. de l'Anat. et de la Physiol., Vol. 36, p. 23.

GoLGI, C. 1908 Di un metodo per la facile e pronta dimostrazione dell'apparato reticolare interno delle cellule nervose. Boll della Societa medicochirugica, Pavia, Anno 22, della Societa, No. 2.

Gотz, Тн. 1908 Untersuchung von Tränendrüsen aus Verschied Lebenaltern. Inaug. Diss. Tüb.

Hannes, Berthold 1911 Ueber das Vorkommen und die Herkunft von Plasmazellen der menschlichen Tränendrüsen. Arch. Path. Anat. Physiol., Bd. 205, S. 410-417.

Heidenhain, M. 1890 Beiträge zur Kenntnis der Topographie und Histologie der Kloake und ihre drüsigen Adnexa bei den einhaemischen Tritonen. Arch. f. Mik. Anat., Bd. 35, pp. 173-74.

Heidenhain, R. 1868 Beitrage zur Lehre von des Speichelabsonderung. Studien d. Physiol. Inst. zu Breslau, Heft. 4, S. 1.

1883 Physiologie der Absonderungsvorgänge. Hermann's Handbuch der Physiologie, Bd. 5, T. 1.

Held, HaNs 1899 Beobächtungen am tierischen Protoplasma I. Drüsen granula und Drüsenprotoplasma. Arch. f. Anat. u. Physiol., Anat. Abt., pp. 284-311.

Hence, J. 1873 Handbuch der sytematischen Anatomie des Menschen, Bd. II, Handbuch der Eigeweidelehre, 2. Auf., pp. 734-745.

Henxhermer 1910 Enzyklopädie der Mikroskopischen Technique Ehrlich, Krause, Mosse, Rosin. Bd. I, p. 451.

Holmgren, E. 1902 Neue Beiträge zur Morphologie der Zelle. Merkel and Bonnet, Ergeb. d. Anat., Bd. 11, p. 274.

HoRnICKer 1906 Vergleichende Untersuchungen über den histologischen Bau der Tränendrüse unserer Haussäugetiere. Internat. Monatschr. f. Anat. u. Physiol., Bd. 23, p. 361.

Hoven, H. 1910 Sur I'histogenèse du système nerveux peripherique chez le poulet et sur le rôle des chondriosomes dans la neuro fibrillation. Arch. de Biol., T. 25, pp. 426-492.

1911 Du. rôle du chondriome dans l'elaboration des produits de sécrétion de la glande mammaire. Anat. Anz., Bd. 39, Nos. 11 u. 12, S. 321-326. Quoted from Schmidt's Jahresb. 46, 1911.

1912 Contribution a l'étude du fonctionnement des cellules glandu. laires. Du rôle du chondriome dans la sécrétion. Arch. f. Zellforsch. Bd. 8. S. 555-611. Quoted from Schmidt's Jahresb. 47, 1912, p. 67.

Iosnnovics, G. 1899 Ueber das Vorkommen die Bedeutung und Herkunft der Unnaschen Plasmazellen bei Verschiedenen pathologisehen Prozessen. Zeitschr. f. Heilk., Bd. 20.

JENDRÁSSIK, E. 1894 Neues Beitrag zur Frage nach der Innervation der Thränendrüse. Orvose. hetl. Budapest, Jg. 38, S. 209 (Ungarisch).

KInGSBURY, B. F. 1911 The histological demonstration of lipoids. Anat. Rec., vol. 5, no. 6, p. 313 .

Kinchstein, F. 1894 Ueber der Tränendrüse der Neugebornen und die Unterscheidung derselben von den Erwachsenen. Inaug. Diss:, Berlin. Quoted after Fleischer. 
KLAPُP, P. 1897 Beiträge zu den Untersuchungen über die Innervation der Thränendrüse. Inaug. Diss., Greifeswald.

KLEIN, 1879 Observations on the structure of cells and nuclei. Quart. Jour. Mic. Sc., vol. 19, p. 125.

1882 ibid., vol. 22.

Kolossow 1898 Eine Untersuchungsmethode des Epithelgewebes besonders der Drüsenepithelium, ete. Arch. f. Mik. Anat., Bd. 52, pp. 1-33.

Kopsch, F. 1902 Die Darstellungen des Binnennetzes in Spinalen Ganglienzellen und andern Körperzellen mitts Osmiumsäure. Sitz.-Ber. d. K. Preuss. Akad. d. Wiss. Math. KI. 40, p. 929.

1910 Golgi method, Enzyplopädie der Mikroskopischen Technique, Ehrlich, Krause, Mosse, Rosin, Bd. 1, p. 564.

Krause, R. 1898 Zur Histologie der Speicheldrüsen. Die Speicheldrüsen des Igels. Arch. f. Mik. Anat., Bd., 45, p. 93.

KÜsEL, W. 1906 Zur Entwickelungsgeschichte der Tränenröhrchen. Zeit. Augenheilk., Bd. 16, pp. 54-57.

LAFFAYE 1897 Recherches sur les glandes lacrymales et leur innervation. Thèse de doctorat en médecine Paris.

Landolt, H. 1900 Ueber die Innervation der Thränendrüse. Habitationsschrift, Strassburg, S. 34.

LaNG, Paul 1911 Zur Entwickelung des Tränenausfuhrapparates beim Menschen. Anat. Anz., Bd. 38, pp. 561-569.

LANGer, C. V. 1890 Lehrbuch der Systematischen und Topographischen Anatomie. Vierte Auflage, p. 647.

LANGLEY, J. M. 1879 On the changes in serous glands during secretion. Jour. of Physiol., vol. 2, pp. 261-281.

1889 On histology of mucous sálivary glands. Jour. of Physiol., p. 433.

Laserstein 1894 Ueber die Anfänge der Absonderungswege in den Speicheldrüsen und im Pankreus. Arch. f. die ges. Physiol., Bd. 55, pp. 417433.

Lavdowsky 1877 Zur feineren Anatomie und Physiologie der Speicheldrüsen, inbesonders der Orbitaldrüse. Arch. f. Mik. Anat., Bd. 13, p. 281.

Lewis, M. R., AND Lewis, W. H. 1914 Mitochondria in tissue culture. Science, vol. 39 , p. 330 .

Leydig, F. 1857 Lehrbuch der Histologie des Menschen und der Tiere. Frankfurt a. M., p. 228.

Lor, L. 1988 Notes Anatomiques, Sur les Glandes de l'Orbite mécconue chez le Lapin. Jour. de l'Anat. et de le Physiol., vol. 34, p. 463.

LuTz 1899 Beiträge zur Kenntnis der Drüsen des dritten Augenlides. Deutsche Zeitschr. f. Tiermedizin. N. F.

Macallum, A. B. 1895 On the distribution of assimilated compounds of iron other than haemaglobin and haematin in animal and vegetable cells. Quart. Jour. Mic. Se., London, vol. 38, pp. 175-274.

MaGGARD 1882 Ueber das Secret und Secretion der Menschlichen Tränendrüse. Virchow Archiv., 89, pp. 258-270.

MaLL, F. P. 1896 Reticulated connective tissue and its relation to the connective tissue fibrils. Johns Hopkins Hospital Reports, vol. 1, p.171. 
Matys, V. 1905-06 Die Entwickelung der Tränenableitungswege. Zeit. Augenheil., Bd. 14, pp. 222-246; Bd. 16, pp. 303-314.

Maximow, A. 1901 Beiträge zur Histologie und Physiologie der Speicheldrüsen. Areh. f. Mik. Anat., Bd. 58, pp. 1-34.

Mazianski, S. 1902 Ueber den Bau und die Einteilung der Drüsen. Anat. Hefte., Bd. 18, pp. 171-237.

Merkel, F. 1883 Die Speichelröhren. Rektoratsprogramm, Rostock. Quoted from Fleischer.

Metzner 1907 Die histologischen Veränderungen der Drüsen bei ihrer Tätigheit. Nagel's Physiol. des Menschen, vol. 2, p. 977.

Michaelis, L. 1899 Die Vitale Farbung, eine Darstellungsmethode der Zellgranula. Arch. f. Mik. Anat., Bd. 55, pp. 558-575.

Milawsky und Smirnow 1893 Zur Lehre von der Speichelabsonderung. Du Bois Arch. Suppl., p. 29.

Monesi, Lugi 1903 Die Morphologie der Fötalen Tränenwebe beim Menschen. Klin. Monat. Augenheilk., Jahrg. 4 , pp. 1-37.

MüLler, E. 1895 Ueber Secretcapillare. Arch. f. Mik. Anat., Bd. 45, p. 463. 1896 Drüsenstudien I. His. Archiv. p. 463.

See also Drüsenstudien II. Zeitschr. f. wiss. Zool., Bd. 64.

Nicolas 1892 Contributions à l'étude des cellules glandulares. Arch. de physiol. norm. et path., Vingtquatrrième année, T. 4., p. 193-208.

Nold, Alfred 1901 Morphologische Veränderung der Tränendrüse bei der Secretion. Arch. f. Mik. Anat., Bd. 58, pp. 487-558.

Nussbaum, M. Ueber den Bau und Tätigheit der Drüsen. Arch. f. Mik. Anat., Bd. 21.

PflüGer Artikel. Speicheldrüsen, in Stricker's Handbuch der Lehre von den Geweben des Menschen und der Thiere, Bd. 1. Quoted from Noll.

Puglisi-Allegra, Stefano 1903 Sui nervi della glandula Iacrymale. Anat. Anz., Bd., 23, pp. 392-393.

1904 Studio della glandula lacrymale. Arch. Ital. Anat. e. Embryol., Firenze, vol. 3, Fasc. 2, pp. 298-340.

Reichel, PAUL 1880 Ueber die Morphologisehen Veränderungen der Tränendrüsen bei ihrer Tätigkeit. Arch. f. Mik. Anat., Bd. 17, pp. 12-13.

Rrquier, Guiseppe C. 1911 Contributo allo studio della glando lacrimale umana. Monit. Zool. Ital., Anno 22, M. 3, pp. 56-65.

SardemanN, E. 1887 Beiträge zur Anatomie der Tränendrüse. Inaug. Diss. Freiburg Preisschrift. Quoted from Hoffmann Schwalbe Jahresb. $16,1,1888$, S. 465 .

SchäFER, E. A. 1912 Textbook of Mikr. Anat., Quain's Anatomy, vol. 2, pt. I, p. 431.

SchlefFerdecker 1884 Zur Kenntnis des Baues der Schleimdrüsen. Arch. \&. Mik. Anat., Bd. 23, p. 382.

SChirmer, O. 1904 Mikroskopische Anatomie und Physiologie der Tränenorgane Im Handbuch der Gesamten Augenheilkunde von Graefe Saemisch. 2 Aufl., 1 Tl., 7 Kap.

SCHMid, KURT 1882 Kernveränderungen in den Secretionszellen. Inaug. Diss. Breslau. 
Schwalbe 1872 Beiträge zur Kenntnis der Drüsen in den Darmwandungen, inbesondere der Brunner'schen Drüsen. Arch. f. Mik. Anat., Bd. 8, p. 92 .

1887 Lehrbuch der Anatomie der Sinnesorgane, pp. 253-255.

SoвоттA, J. 1902 Atlas und Grundriss der Histologie und Mikroskopischen Anatomie des Menschen. Lehman, München, pp. 238-39.

Solger, B. 1896 Ueber den feineren Bau der Glandula Submaxillaris des Menschen mit besondere Berücksichtigung der Drüsengranula. Festschrift f. Gegenbaur. Leipsig. Quoted from Fleischer.

Spalteholz, W. 1897 Das Bindgewebesgerüst der Dündarmschleimhaut des Hundes. Arch. f. Anat. u. Physiol., Anat. Abt. Supl., Bd. 1, p. 273.

Speciale-Crrincione 1908 Ueber die Entwickelung der Tränendrüse beim Menschen. Arch. Ophthalm., Bd. 69, pp. 193-230. Quoted from Schwalbe's Jahresb.

Stanculéanu und Théorhari 1898 Etat de la glande lachrimale dans Larmoiement chronique. Arch. f. Ophthalm., 18, S. 737.

SToнR 1887 Ueber Schleimdrüsen. Festschrift f. v. Kölliker.

1891 Lehrbuch der Histologie des Menschen, 4 Auf., Jena, pp. 249-250.

Sundwalu, J. 1906 The Harderian Gland of the Ox. Anat. Rec, vol. 1, no. 4, p. 72 .

Teptiachine 1894 Recherches sur les nerfs sécretoires de la glande lacrymale. A. d. ophthalmol., Paris, Année 14, pp. 401-413.

UNNa 1892 Ueber die Bedeutung der Plasmazellen etc., Berl. Klin. Wschr.

Unna-Taenzer 1910 Enzyk. der Mik. Tech., vol. 1, p. 394.

Van Trotzenburg 1901 Petrus Camper D. 208-227, Reviewed from Schwalbe's Jahresb.

WaLDEYeR 1875 Reference in Enzyk. Mik. Tech., 1910, vol. 2, p. 409.

Wredensherm, R. 1876 Die Kopfdrüsen der geschwänzten Amphibien und die Glandula intermaxillaris der Anuren. Zeitschr. f. wsch. Zool., Bd. 27. 1907 Comparative Anatomy of Vertebrates, Parker's Translation, p. 288 .

ZimmermanN 1898 Beiträge zur Kenntnis einiger Drüsen und Epithelium. Arch. f. Mik. Anat., Bd. 52, p. 552.

All drawings are made from preparations of the lachrymal gland obtained from Bovidae. 